\title{
Fault and graben growth along active magmatic divergent plate boundaries in Iceland and Ethiopia
}

\author{
Trippanera D. ${ }^{1 *}$, Acocella V. ${ }^{1}$, Ruch J. ${ }^{{ }^{1}}$, Abebe B. ${ }^{2}$ \\ ${ }^{1}$ Roma Tre University, Rome, Italy \\ 'Now at King Abdullah University of Science and Technology (KAUST), Thuwal, Saudi Arabia. \\ ${ }^{2}$ University of Addis Ababa, Addis Ababa, Ethiopia \\ *Corresponding author: daniele.trippanera@uniroma3.it
}

1
4
4

\begin{abstract}
Recent studies highlight the importance of annual-scale dike-induced rifting episodes in developing normal faults and graben along the active axis of magmatic divergent plate boundaries (MDPB). However, the longer-term $\left(10^{2}-10^{5}\right.$ years) role of diking on the cumulative surface deformation and evolution of MDPB is not yet well understood. To better understand the longer-term normal faults and graben along the axis of MDPB, we analyze fissure swarms in Iceland and Ethiopia. We first focus on the simplest case of immature fissure swarms, with single dike-fed eruptive fissures; these consist of a $<1 \mathrm{~km}$ wide graben bordered by normal faults with displacement up to a few meters, consistent with theoretical models and geodetic data. A similar structural pattern is found, with asymmetric and multiple graben, within wider mature fissure swarms, formed by several dike-fed eruptive fissures. We then consider the lateral termination of normal faults along these graben, to detect their upward or downward propagation. Most faults terminate as open fractures on flat surface, suggesting downward fault propagation; this is consistent with recent experiments showing dike-induced normal faults propagating downward from the surface. However, some normal faults also terminate as open fractures on monoclines, which resemble fault propagation folds; this suggests upward propagation of reactivated buried
\end{abstract}

This article has been accepted for publication and undergone full peer review but has not been through the copyediting, typesetting, pagination and proofreading process which may lead to differences between this version and the Version of Record. Please cite this article as doi:

10.1002/2015TC003991 
faults, promoted by diking. These results suggest that fault growth and graben development, as well as the longer-term evolution of the axis of MDPB, may be explained only through dike emplacement and that any amagmatic faulting is not necessary.

Key words: magmatic divergent plate boundaries, normal fault, graben, dike, rifting, Iceland, Ethiopia

\section{Introduction}

Magmatic divergent plate boundaries (MDPB) are characterized by two tectonic plates that spread apart from each other and may be found on oceanic, transitional or continental lithosphere. These boundaries consist of several magmatic systems, where faulting and volcanic activity focus. A magmatic system is usually composed of a dominant volcano and fissure swarms radiating from it along the rift axis, characterized by eruptive fissures, extension fractures and normal faults [Gudmundsson, 1995a, Gudmundsson 2000; Ebinger and Casey, 2001; Acocella, 2014]. Eruptive fissures consist of aligned dike-fed vents, and may reach along-rift lengths of several tens of $\mathrm{km}$. Extension fractures are hundreds of meters long and generally less than 1-2 m wide. Normal faults often form graben or halfgraben structures and are thousand of meters long; the shallowest part of these faults along the rift axis commonly display a dilational (tensile) component, up to $\approx 5 \mathrm{~m}$, between the footwall and the hanging wall; the latter is often tilted toward the downthrown side; such a fault structure, uncommon in sedimentary sequences, may result from the strength of the basaltic lavas and welded tuffs [Martel and Langley, 2006; Hardy, 2013]. The lateral termination of the normal faults is characterized by the progressive decrease in the vertical displacement, which reaches zero and leaves only open fracture separating the two portions of the fault [Gudmundsson, 1992; Angelier et al., 1997; Acocella et al., 2003; Acocella, 2014].

The development of normal faults and extension fractures along the axis of MDPB has been directly related to regional extension or magmatism. In the first case, plate pull creates tension fractures at the surface; when growing, these reach a critical depth where the growing lithostatic stress imposes a shear component, developing normal faults 
[Gudmundsson and Backstrom 1991; Forslund and Gudmundsson, 1992; Gudmundsson, 1992; Acocella et al., 2003]. According to this model, the normal faults nucleate immediately below the surface, at few hundreds of $m$ of depth, and propagate downward. However, favorably oriented pre-existing normal faults, buried by volcanic and volcaniclastic basin fill, may be reactivated, propagating upward [e.g. Podolsky and Roberts, 2008].

In the second case, modelling, geodetic and geophysical studies have highlight the importance of magma, in the form of dike injections (or diking), in separating the plates and controlling the structure and development of divergent plate boundaries, particularly when initiating or reactivating the normal faults [e.g. Buck, 2006; Sigmundsson, 2006a; Wright et al., 2006]. The dikes inferred to be responsible for plate spreading and for shaping the shallow structure of divergent plate boundaries are usually tens of $\mathrm{km}$ long, several $\mathrm{m}$ wide and propagate within a few days or weeks along the fissure swarm [e.g. Ebinger et al., 2010; Sigmundsson et al., 2015]; if reaching the surface, they also feed eruptive fissures. Dike-induced faults are interpreted to nucleate at depth, in correspondence with the upper dike tip, and then propagate upward. At the surface, the upward propagating normal faults first generate a monocline due to the bending above their upper tip; this is subsequently displaced by the propagated fault, accordingly to established fault propagation folding models: the final result is a faulted fold, or monocline [Grant and Kattenhorn, 2004; Tentler, 2005; Martel and Langley, 2006; Rowland et al., 2007; Ferrill et al., 2012, and references therein].

The emplacement of a single dike (producing a rifting event) or multiple dikes along the same rift portion within a decade (producing a rifting episode) creates an immature fissure swarm; this consists of a dike-fed eruptive fissure and a narrow ( $<1 \mathrm{~km}$ wide) zone of associated extension fractures and normal faults. Repeated rifting events or episodes, with a recurrence interval of a few centuries [Ebinger et al., 2010], produce a mature fissure swarm, consisting of multiple dike-fed eruptive fissures and associated extension fractures and normal faults. Important recent rifting episodes include Krafla 1975-1984 (Iceland), Asal 1978 (Afar), Dabbahu 2005-2009 (Afar), whereas rifting events include Dallol 2004 (Afar), Natron 2007 (Tanzania), Harrat Lunayyir 2009 (Saudi Arabia), Bardarbunga 2014-2015 (Iceland); these episodes and events have been geodetically and seismically constrained, 
showing that the deformation pattern at the surface commonly results in a graben structure [e.g. Bjornsson, 1977; Ruegg, 1979; Tarantola et al., 1980; Tryggvason, 1984; Rubin and Pollard, 1988; Wright et al., 2006; Biggs et al., 2009; Pallister et al., 2010; Nobile et al., 2012; Gudmundsson et al., 2014; Sigmundsson et al., 2015]. However, field investigations on the structural features developed at the surface have been limited [e.g., Sigurdsson, 1980; Rowland et al., 2007; Pallister et al., 2012]. Despite the evidence that single normal faults may be effectively reactivated with slip of a few meters during diking, as at Dabbahu [Rowland et al., 2007], little is known on the structural effect of diking at the surface. This limitation is particularly relevant for the longer-term $\left(10^{2}-10^{5}\right.$ years) rift structure, resulting from repeated diking events or episodes, as well as from any regional tectonic activity during rifting (as at Lake Natron, Tanzania, in 2007; [Calais et al., 2008]) or inter-rifting episodes (e.g., Doubre and Peltzer, 2007). Analysis of the longer-term structure of a rift may better define the magmatic and tectonic processes controlling normal fault and graben formation and growth along the axis of MDPB. In particular, it may be possible to better understand how faults grow and propagate and how much of this growth and propagation may be ascribed to diking and/or regional processes: this may ultimately define the relative importance of the magmatic and amagmatic contributions in shaping MDPB.

This study aims to better define: a) the structural features (geometry and kinematics) of normal faults along the active axis of MDPB, b) their possible mechanisms of growth on the longer-term $\left(10^{2}-10^{5}\right.$ years), including the development of graben structures and, possibly, the contribution of magmatic and amagmatic processes. To this aim, we performed a field survey at selected locations along the axis of oceanic and, subordinately, transitional and continental divergent plate boundaries of Iceland and Ethiopia. Despite the fact that there is a continuum in the evolutionary spectrum of known fissure swarms, in the field analysis we have distinguished two main end-member types (immature and mature swarms), trying to reconcile known cases to these types. This allows to focus first on the simplest case of the immature fissure swarms, to define deformation patterns related to diking, and then on the more complex case of the mature fissure swarms, also trying to compare both endmembers of fissure swarms. We also considered the lateral termination of the normal faults, to define any sense or upward or downward propagation and relate this to tectonic or diking 
processes. All these observations suggests that the longer-term deformation pattern observed along divergent plate boundaries may be explained by shallow dike emplacement.

\section{Tectonic setting}

Iceland marks the subaerial portion of the Mid-Atlantic Ridge, separating the North American from the Eurasian plates at a rate of $\sim 2 \mathrm{~cm} / \mathrm{yr}$ [Fig. 1a; e.g. DeMets et al., 2010]. Three main neovolcanic rift zones characterized the active portion of the MDPB in Iceland with 1) the Reykjanes-Langjokull Volcanic Zone (RLVZ) to the East, 2) the North Volcanic Zone (NVZ) and 3) the Eastern Volcanic Zone (EVZ), to the South of NVZ. The RLVZ includes the obliquely spreading Reykjanes Peninsula Rift to the SW, and the Western Volcanic Zone (WVZ) to the NE, comprising the Hengill-Langjokull magmatic systems. The WVZ has been the main locus for crustal spreading in South Iceland for the last 6-7 Ma. To the East, the NVZ has been active for 6-7 Ma to the North of the Vatnajokull icecap and the EVZ has been active for 2-3 Ma (Fig. 1a). The EVZ is propagating southwards, and significant crustal spreading in the EVZ has only developed North of the Torfajokull volcano. The EVZ and WVZ have an overlapping configuration in southern Iceland. There the spreading rate of the EVZ decreases southward, while it increases linearly southwards along the WVZ, maintaining an overall constant total velocity [LaFemina et al., 2005; Perlt et al., 2008]. The area enclosed by the EVZ and the WVZ forms the South Iceland Seismic Zone, able to generate >M7 earthquakes, related to the early development of a transformlike feature [Gudmundsson and Brynjolfsson, 1993; Gudmundsson, 1995b; Gudmundsson, 2007; Angelier et al., 2008; Clifton and Kattenhorn, 2006]. Post glacial volcanism is focused along the active rift axis, composed of a dozen magmatic systems [Gudmundsson, 1987b, 1995b, 2000; 'Rubin and Pollard, 1988]. Usually, each magmatic system, 40-150 km long and 5-20 km wide, is activated by along-rift diking episodes with a frequency of few hundreds of years [Sigmundsson, 2006a]. The eroded Late Tertiary and Pleistocene lava pile on the eastern and western sides of Iceland allows us to study the deeper portion of extinct magmatic systems, constituted by $50 \mathrm{~km}$ long and 5-10 km wide dike swarms. These represent a rare possibility to observe and analyze the extinct roots of the magmatic systems, whose fissure swarms are currently observed at the surface along the active 
portions of the MDPB. The dike swarms on the eastern and western sides of Iceland are composed of subparallel vertical dikes and are $<10 \mathrm{~km}$ wide and tens of $\mathrm{km}$ long. At depth of 1-2 km, these swarms are composed of hundreds of parallel dikes having a mean thickness of 3-4 m, accommodating $\sim 5-6 \%$ of crustal dilation, with very few faults [Walker, 1958; 1960; Gudmundsson, 1984; Helgason and Zentilli, 1985; Gudmundsson, 1995a; Paquet et al., 2007].

In Ethiopia, our attention focuses on the transitional crust of Afar (northern and central Afar) and the continental Main Ethiopian Rift (MER) (Fig. 1b). Afar results from a late Eocene-early Oligocene uplift due to the presence of a mantle plume and the successive fragmentation of the Arabian-Nubian shield. This led to the development of a triple junction, with the separation of the Nubian, Arabian and Somalian plates along the Gulf of Aden, the Red Sea and the MER [McKenzie et al., 1970; Barberi and Varet, 1977; Le Pichon and Francheteau, 1978; McClusky et al., 2010]. The mean spreading rates of the Aden Rift and the northern portion of the Red Sea Rift are $\sim 1.1$ to $\sim 1.5 \mathrm{~cm} / \mathrm{yr}$ [Cattin et al., 2005; Walpersdorf et al., 1999; Vigny et al., 2007] and $1.6 \mathrm{~cm} / \mathrm{yr}$ [Jestin et al., 1994; McClusky et al., 2010] respectively, higher than the MER [Bilham et al., 1999; Bendick et al., 2006; Kogan et al., 2012]. Therefore, most of the strain in Afar results from the activity and interaction of the Aden and Red Sea rifts, propagating onland with an overlapping configuration; this induces Quaternary clockwise rotations of crustal blocks about a horizontal axis, resulting in a bookshelf faulting mechanism in Central Afar [Courtillot et al., 1984; Tapponnier et al., 1990]. There is a northward and eastward shallowing of the Moho below Afar, with the transition from a continental to an oceanic segmentation of the tectonomagmatic features [Ebinger and Hayward, 1996]. Magmatic activity has accompanied the development of the Afar depression through three main stages [e.g. Barberi and Varet, 1977; Barberi et al., 1980; Lahitte et al., 2003a], with: 1) the emplacement of the widespread and $>1500 \mathrm{~m}$ thick "Stratoid" sequence made up of flood basalts and ignimbrites marking the transition to an oceanic crust, from 4 to 1 Ma [Barberi et al., 1975; Barberi and Santacroce, 1980]; 2) the development of dominant silicic volcanoes as precursors to rift propagation in the last 2 Ma [Lahitte et al., 2003b]; 3) the current oceanic- 
type basaltic volcanism, along the active rift zones, mainly through eruptive fissures along fissure swarms [Barberi et al., 1972a; 1972b].

In recent times, several diking episodes and events, all accompanied by seismicity and surface deformation, affected the evolution of the Afar region. The Asal rift (A in Fig. 1b) underwent a diking episode in 1978, controlling co- and post-intrusive fault slip at the surface [Jacques et al., 1996; Cattin et al., 2005; Vigny et al., 2007; Pinzuti et al., 2010]. The Northern Red Sea Rift underwent a rifting event in Dallol in 2004 (D in Fig. 1b), when a dike formed a geodetically detected graben-like structure, reactivating a regional normal fault [Nobile et al., 2012]. The southern part of the Red Sea rift in Dabbahu (Da in Fig. 1b), in the northern Manda Hararo Rift ( $M$ in Fig. 1b), underwent a dike-induced rifting episode from 2005 to 2010. The major intrusion event, in 2005, emplaced a $60 \mathrm{~km}$ long and $8 \mathrm{~m}$ thick dike, with a minor eruption, >M5 earthquakes and significant surface deformation, reactivating pre-existing normal faults with displacement of up to $3 \mathrm{~m}$ [Wright et al., 2006; Ayele et al., 2007; Rowland et al., 2007; Grandin et al., 2009]. This shows that normal faults along the rift axis may result from past diking events and episodes and thus magma may be responsible for the axial relief of the fissure swarms along a magmatic segment [Rowland et al., 2007]. Dabbahu has highlighted the importance of episodic (approximate century interval) and rapid magma emplacement in the opening of a rift and thus in plate boundary deformation [Sigmundsson, 2006b; Wright et al., 2006; Ayele et al., 2007; Ebinger 2010]. Finally, a rifting episode possibly occurred in the Southern Red Sea ridge, forming two new volcanic islands in the Zubair Archipelago (Xu et al., 2015).

The MER, to the South of the Afar depression, separates a portion of the Nubia and Somalia plates at a rate of 4-7 mm/yr [Fig. 1b; e.g. DeMets et al., 2010]. The NE-SW trending MER developed in two main stages controlled by oblique opening [Corti, 2008; 2009]. An early (Mio-Pliocene) continental rifting stage activated the NE-SW striking rift border faults, creating up to $5 \mathrm{~km}$ of subsidence, and was associated with diffuse magmatic activity, also off-rift axis. In this period, rift development was primarily controlled by the lithospheric structure. In the later, Quaternary stage magmatic processes become dominant, focusing the tectonic, seismic and magmatic activity in systems along the rift axis, called "Wonji Fault Belt" (WFB) (Fig. 1c) and partly deactivating the main border faults 
[Woldegabriel et al., 1990; Ebinger and Casey, 2001; Ebinger, 2005; Keir et al., 2006; Keranen and Klemperer, 2008; Corti, 2009]. The WFB consists of several NNE-SSW striking right-stepping en-echelon magmatic systems and associated fissure swarms, $\sim 20$ $\mathrm{km}$ wide and $\sim 60 \mathrm{~km}$ long [Mohr, 1967; 1987], developing extension fractures, normal faults and graben [Acocella and Korme, 2002; Acocella et al., 2003]. These magmatically supplied WFB systems accommodate $>80 \%$ of the strain across the rift at depths $<10 \mathrm{~km}$ [Bilham et al., 1999] and are considered the loci responsible for the opening of the rift, similar to what observed along oceanic ridges. Magma accumulates below the dominant volcano, where it may be erupted or intruded laterally through sub-vertical dikes along the fissure swarm, feeding fissure volcanism [Ebinger and Casey, 2001; Casey et al., 2006]. Seismicity is also focused along the magmatic systems and along the fissure swarm and is interpreted as evidence for faulting and/or magma intrusions [e.g. Keir et al., 2006]. The shallowest crustal portion beneath the central portion of the MER, between 7-25 km, is characterized by high $\mathrm{P}$-wave velocities coinciding with gravity maxima, suggesting cooled magmatic intrusions that accommodate a large part of extensional strain at depth. These $\sim 20 \mathrm{~km}$ wide and $\sim 50 \mathrm{~km}$ long bodies in a right stepping en-echelon pattern, approximately mimicking surface segmentation of the Quaternary magmatic systems [Keranen et al., 2004; Mickus et al., 2007; Daly et al., 2008]. In the upper mantle, shear-wave splitting suggests a strong component of melt-induced anisotropy, supporting a magma-assisted rifting model in continental lithosphere [Kendall et al., 2005]. GPS measurements between 1992-2010 indicate an extension rate of $8 \mathrm{~mm} / \mathrm{yr}$, distributed across the northern MER and focused in the southern MER [Kogan et al., 2012]. The extension rate between 1992-2010 is consistent with velocity field models from permanent GPS stations on Africa between 1996-2003, suggesting that the Nubia and Somalia plates on the flanks of the MER separate at $\sim 7 \mathrm{~mm} / \mathrm{yr}$ [Fernandes et al., 2004]. These geodetic estimates are at least one order of magnitude larger than the geological ones, measuring the cumulative extension of faults and extension fractures on deposits of known age in the field; this suggests that, along the rift axis, most of the extension is accommodated at depth or that plate spreading does not occur at a uniform rate [Williams et al., 2004]. 
More details on the structural features of portions of Iceland and Ethiopia are given at the beginning of each studied area, in the result section.

\section{Methods}

Our field surveys focused on the surface deformation along selected portions on oceanic (Iceland) and, subordinately, transitional and continental (Afar and MER) crustal types. In particular, the surveys defined the structural features of the normal faults and related graben structures along the axis of MDPB, with the aim to understand how faults and graben grow and, in turn, constraining the longer-term contribute of magmatism (diking) or amagmatic faulting (regional tectonics) in the development of MDPB and their structures.

The surveys were preceded by a preliminary remote sensing study, with the aim to: a) identify the most promising and accessible fissure swarms in the field; b) provide an overview of the geology and structure of the area. The remote sensing study was based on satellite images freely available on Google Earth for most of the areas (for details on the images: https://en.wikipedia.org/wiki/Google_Earth), with a resolution between 2.5 and 15 meters. In some cases, we used aerial photos (resolution $<1 \mathrm{~m}$ ) and SPOT 5 images (resolution $2.5 \mathrm{~m}$ ) available from the National Land Survey of Iceland (http://atlas.Imi.is; http://www.Imi.is/), as well as published maps (especially for the areas of Lakagigar and Thingvellir; [Gudmundsson, 1987; Saemundsson, 1992; Thordarson and Self, 1993]). All the structural features we preliminarily identified through the remote sensing analysis were then imported into the ArcGis software, for georeferencing and further analysis. This included defining, for each fissure swarm, the largest and most important structural features (i.e. normal faults, extension fractures, graben), as well as their spatial extent, configuration and relationships to eruptive fissures.

Based on these analyses and data from literature, we distinguished between: a) immature fissure swarms with one or two eruptive fissures, characterized by a narrow deformation zone (hundreds of $\mathrm{m}$ wide, e.g. Eldgjá, Laki, Sveinagja, Sveinar, in Iceland; Erta Ale, in Afar), that are related to single or very few diking events or episodes; this latter feature can be deduced from the presence of a single, continuous or interrupted, alignment of vents; b) mature fissure swarms, hosting several eruptive fissures with a wider (a few $\mathrm{km}$ ) 
area of normal faults and eruptive fissures (e.g. Krafla, Vogar, Thingvellir in Iceland and Fantale and Manda Hararo in Ethiopia).

In the field, at each selected area, we first considered the overall structure of the fissure swarm, as given by the dominant extension fractures and fault systems, which have been geometrically and kinematically characterized. From a geometric point of view, we were able to directly characterize the structures observed through remote sensing and fully define their configuration and spatial extent in the field, also identifying minor structures not visible at the remote sensing scale. In addition, we were able to measure the structures with much higher resolution $(<1 \mathrm{~m})$ than that obtained from the remote sensing analysis. From a kinematic point of view, we systematically measured the opening of the extension fractures and the faults, as well as the vertical throw, dilation and hanging wall tilt of the normal faults, if present (Fig. $2 \mathrm{a}, \mathrm{b}$ ). These measures were taken at representative sites of the structures with a $20 \mathrm{~m}$ long meter tape and produced an error which we estimated as $<5 \%$ of the measurement we made: our measurements were usually in the order of a few $m$ (for the opening and throw of the structures) or of a few degrees (for the hanging wall tilt). Most of the kinematic data were collected on the major structures detected though the remote sensing analysis, even though in some cases we were also able to locally characterize the kinematic features of minor structures, to provide a more complete and robust dataset.

The upward or downward propagation of the normal faults may help to discriminate their tectonic and/or magmatic origin along the axis of magmatic divergent plate boundaries. Therefore, in the field we also tried to evaluate the upward or downward sense of normal fault propagation. This has been done considering the structure of the lateral tip of the fault at the surface: at the tip, the displacement reduces to zero and therefore the structure of the lateral tips may provide insight to fault growth and on the mode of propagation of the fault. The structure of the lateral tip of the normal faults can be summarized in two main types [Cartwright and Mansfield, 1998]. a) The fault tip displays a flat footwall and a flat hanging wall, interrupted by extension fractures departing from the main fault (open fracture or OPF type; Fig. 2c); features interpreted to support the notion that the fault formed from the coalescence of open fractures and propagated downward. b) The fault tip displays a flat footwall and an outward tilted hanging wall interrupted by an extension fracture, resembling 
an overall fractured monocline; this structure suggests a fault propagation folding mechanism associated with an upward or lateral propagation of the fault (fault propagation folding or FPF type; Fig. 2d). An important part of our field survey consisted of a detailed mapping of the lateral tips of the normal faults, where the faults displacement becomes zero, in order to identify the type of lateral termination: in particular, we distinguished between a flat or tilted hanging wall to the side of the extension fracture at the fault tip. Most fault tips were measured in areas of general flat topography. In a few cases, the normal fault tips were on a gentle slope, extending both on the footwall and the hanging wall over a distance much larger (hundreds of $m$ or more) than that which may be related to the activity of a fault propagation fold (less than several tens of meters). In these cases, the tilt due to this broader slope was distinguished from that eventually present in the hanging wall. In general, except for a very few exceptions, as for example where a road passing along the fault tip masked the structure, we were able to systematically and unambiguously define the type of propagation (OPF or FPF) of the fault.

\section{Results}

Here we present the results of the structural pattern observed along 10 fissure swarms (section 4.1 and 4.2) in Iceland and Ethiopia. All the presented data are original, except for a part of those from the areas of Vogar and Thingvellir, Iceland, presented in Norini et al., 2009, and part of those from Erta Ale and Manda Hararo, Ethiopia, presented in Acocella, 2006, and Acocella et al., 2008, respectively.

\subsection{Immature fissure swarms}

\subsubsection{Lakagigar (Iceland)}

The $27 \mathrm{~km}$ long Lakagigar eruptive fissure is located in SE Iceland, in an area undergoing an overall extension rate of $10 \mathrm{~mm} / \mathrm{yr}$ (Table 1) [Perlt et al., 2008]. The fissure belongs to the Grimsvotn magmatic system (East Volcanic Zone) and formed in 1783-1784 $A D$, producing one of the largest historical basaltic lava flows $\left(\sim 15 \mathrm{~km}^{3}\right)$; the feeder dike(s) propagated towards NE, forming ten en-echelon fissures [Thordarson and Self, 1993]. Our 
field survey focused on the $\sim 4 \mathrm{~km}$ long central portion of the fissure in a nearly flat area, except for the $\sim 200 \mathrm{~m}$ high and older Laki hill (Fig. 3). The $\mathrm{N} 45^{\circ} \pm 5^{\circ}$ (the error is referred to the $95 \%$ confidence) striking fissure (Fig. 3d) is mostly centered within a graben bordered by $N 55^{\circ} \pm 5^{\circ}$ trending normal faults with mean dip of $75^{\circ}$ (Fig. 3a, b, c). In the flat areas North and South of Laki, the graben is $150-450 \mathrm{~m}$ wide. In correspondence to Laki the border faults climb the hill, enlarging up to $\sim 700-800 \mathrm{~m}$ apart; the deformation is accompanied by diffuse fracturing, given by additional normal faults and also extension fractures, as well as two small eruptive fissures on the northern slope of the hill (Fig. 3b).

The mean vertical throw of the border normal faults along the fissure is 3-5 $\mathrm{m}$, locally reaching $10 \mathrm{~m} \sim 1.5 \mathrm{~km}$ North of Laki hill (Fig. 3e; Table 1); this locally higher displacement may have been enhanced by the topography of the hill. In addition, a mean tensile component of $\sim 1.4 \mathrm{~m}$ is found between the footwall and the hanging wall of the faults (Fig. 3f). The hanging wall and the footwall are usually outward tilted of $5^{\circ}-10^{\circ}$ (Fig. $3 \mathrm{c}$ ). The deformation on the border faults may be locally partitioned into several minor parallel normal faults, resulting in a widespread and less defined border (Section A-A'; Fig. 3g). The eruptive fissure, usually located in the middle of the graben, may also locally coincide with the border fault (Section B-B'; Fig. 3g). This suggests that the border fault formed before the dike reached the surface and was subsequently reactivated by the rising dike. Finally, the lateral termination of 8 normal faults bordering the graben shows open fracture structures (OPF type), suggesting that the normal faults nucleated at the surface and propagated downward (Table 1). This conclusion is also supported by the lack of any visible pre-existing fault and the only faults present today are those, with a collinear configuration, induced by the 1783 dike during its propagation [Thordarson and Self, 1993]; this allows us to exclude any tensile stress anomaly induced by the interaction between fault segments.

\subsubsection{Eldgjá (Iceland)}

The $75 \mathrm{~km}$ long and $\mathrm{N} 45^{\circ} \mathrm{E}$ trending Eldgjá graben and associated eruptive fissure belongs to the fissure swarm of the Katla magmatic system (Iceland; Fig. 1). The area is undergoing an overall extension rate is $9 \mathrm{~mm} / \mathrm{yr}$ (Table 1) [Perlt et al., 2008]. Eldgjá results from at least two distinct rifting episodes; the last one in 933-941 AD [Hammer, 1984; 
Zielinsky et al., 1995], produced a total erupted volume of $\sim 20 \mathrm{~km}^{3}$. Eldgjá can be divided in three main sectors: a SW, a Central and a NE sector [Thordarson et al., 2001]. Our field survey focused on a $1 \mathrm{~km}$ long segment of the SW and Central sectors and on a $4.5 \mathrm{~km}$ long segment of the NE sector. All the sectors host a main graben structure and in some cases an eruptive fissure. The graben has generally discontinuous (200-300 m long) inward dipping normal faults, localized minor parallel faults and minor nested graben (Fig. 4a). The eruptive fissures are located within the graben and partly bounded by the normal faults. They also partly coincide with the border faults, similarly to Laki (Fig. 4b). In the investigated area, the $\mathrm{N} 35^{\circ} \pm 5^{\circ}$ to $\mathrm{N} 65^{\circ} \pm 5^{\circ}$ oriented eruptive fissure mainly crops out in the Central sector. The mean width of the graben containing the fissure is $230 \pm 10 \mathrm{~m}$ in the SW, $160 \pm 10$ $\mathrm{m}$ in the Central and enlarges to $650 \pm 10 \mathrm{~m}$ in the NE sectors (Fig. 4a, b, c; Table 1). However, the overall mean strike and throw of the border faults, of $N 40^{\circ} \pm 5^{\circ}$ and $5 \pm 0.5 \mathrm{~m}$, respectively, remain consistent throughout the sectors (Fig. 4d, e; Table 1). In each sector, the fault throw of the border faults reaches up to $10 \pm 2 \mathrm{~m}$ (Table 1). The mean fault dip, estimated in four well-exposed sections, is $78^{\circ} \pm 4^{\circ}$ (i.e. Fig. 4h). Locally, the footwall and the hanging wall of the border faults are separated by a tensile fracture 0.5 to $4 \mathrm{~m}$ wide (mean value of $1.5 \pm 0.2 \mathrm{~m}$; Fig. $4 \mathrm{f} ;$ Table 1 ). In correspondence to the SW and Central sectors, a regional tilt of $\sim 10^{\circ}$ toward SE has been observed, also on the footwall and hanging wall of the border faults (Fig. 4a). Along these two sectors, the hanging wall tilt of the border faults towards the graben center is uncommon ( $<20 \%$ of the observations in the SW and central segment, respectively; Table 1). In the NE segment, the border faults display a dilational component; the footwall is flat or $10^{\circ} \pm 5^{\circ}$ tilted outward with respect to the graben axis, whereas the hanging wall is commonly ( $76 \%$ of the observations) tilted toward the graben axis, with mean dip of $20^{\circ}$ (Fig. $4 \mathrm{~g}$; Table 1). In between the hanging wall and the footwall, the tensile fracture is $2 \pm 0.5 \mathrm{~m}$ wide (Fig. 4i). At the northern termination of the graben, the tips of two border faults show fault propagation folds (FPF type; Fig. 4c).

\subsubsection{Sveinagja (Iceland)}

The $34 \mathrm{~km}$ long and $\sim 1.5 \mathrm{~km}$ wide Sveinagja graben is located within the fissure swarm of the Askja magmatic system, undergoing an overall extension of $19 \mathrm{~mm} / \mathrm{yr}$ (Table 1) [Perlt 
et al., 2008]. In the northern portion of the central graben, a fissure eruption related to the 1872-1875 AD rifting episode produced $0.3 \mathrm{~km}^{3}$ of lava (Fig. 5a). This episode is also coeval with the formation of the Oskjuvatn caldera, in the $70 \mathrm{~km}$ distant Askja dominant volcano [Sigurdsson and Sparks, 1978]. In 1872-1875, the Sveinagja graben probably reactivated, as it formed during an older rifting episode [Gudmundsson and Backstrom, 1991; Tentler and Mazzoli, 2005].

Our field survey focused along a $4 \mathrm{~km}$ long segment of the northern portion of the graben, where the eruptive fissure is centered within (Fig. 5a). Here the graben is $\sim 1 \mathrm{~km}$ wide, with border faults striking $\mathrm{N}^{\circ} \pm 0^{\circ}$ (Fig. 5b). The highest measured fault throw of the border faults is $\sim 10 \mathrm{~m}$, whereas the average normal displacement is $\sim 4 \mathrm{~m}$ (Fig. $5 \mathrm{c}$ ). These data are consistent with previous studies [Gudmundsson and Backstrom, 1991; Tentler, 2005; Tentler and Mazzoli, 2005]. The faults are subvertical at the surface, usually showing a dilational component between the footwall and the hanging wall. The tensile area is usually $\sim 2 \mathrm{~m}$ wide, locally reaching up to $>10 \mathrm{~m}$. The geometry of the faults also varies along strike. Both the footwall and the hanging wall are usually subhorizontal, but in $40 \%$ of the observations the hanging wall may be tilted toward the down-thrown side up to $20^{\circ}$ (Fig. $5 \mathrm{~d}$; Table 1). Each border fault system may locally consist of a smaller graben-like structure, 20-40 m wide, with a subsided block between the footwall and the hanging wall. The five border fault segments terminate in a series of open fractures on flat topography, suggesting an OPF type of lateral termination of the normal faults.

\subsubsection{Sveinar (Iceland)}

The 0.5 to $0.8 \mathrm{~km}$ wide and $20 \mathrm{~km}$ long Sveinar graben lies $\sim 30 \mathrm{~km}$ North to Sveinagja. The Sveinar graben belongs to a fissure swarm of the Fremri-Namur magmatic system and formed mainly during the eruption of the Sveinar Lava, 6000-8000 years ago [Gudmundsson and Backstrom, 1991]. This eruption developed the NNE-SSW trending Rauduborgir-Randarholar eruptive fissure, partially contained within the graben (Fig. 6a).

The graben continued to develop during the 1875 rifting episode at Askja-Sveinagja [Thorarinsson, 1959; Sigurdsson and Sparks, 1978; Gudmundsson and Backstrom, 1991; Tentler and Mazzoli, 2005]. As a detailed analysis of the overall graben structure has been 
already provided [Tentler and Mazzoli, 2005], here we focused on the northernmost $1.5 \mathrm{~km}$ of the eastern border of the graben (Fig. 6b). This is formed by three main normal faults striking almost $\mathrm{N}-\mathrm{S}$ (mean strike $\mathrm{N} 6^{\circ}$ ). The faults are subvertical at the surface and show a mean vertical throw of $\sim 4 \mathrm{~m}$, locally reaching $8 \mathrm{~m}$, much smaller than the maximum throw of $23 \mathrm{~m}$ in central portion of the graben, out of the investigated area [Tentler and Mazzoli, 2005]. The studied fault segment shows an open fault with dilational component between the footwall and the hanging wall up to $2 \mathrm{~m}$ wide. In general, the footwall and the hanging wall are flat, consisting of horizontal layers. Locally, the border fault is also accompanied by antithetic structures, forming minor and narrow graben (Fig. 6b). Along $\sim 200 \mathrm{~m}$ of the northern fault segment, the hanging wall is usually tilted of $20-25^{\circ}$ (Fig. 6c), at times becoming subhorizontal or, conversely, reaching $65^{\circ}$ and becoming subvertical at the hanging wall base (Fig. $6 \mathrm{~d}, \mathrm{e}$ ). The throw and the hanging wall tilt along the southern segment gradually decrease southwards and the fault grades into a series of open fractures with a minor graben-like structure, within a flat topography area (Profile D-D'; Fig. 6b). This portion of the Sveinar graben highlights the coexistence of important variations in the dip of the hanging wall of the central portion of a border fault within a limited area, a few hundreds $\mathrm{m}$ long.

\subsubsection{Erta Ale (Ethiopia)}

The Erta Ale Range lies along the northern proto-oceanic part of the NW-SE trending Red Sea Rift in Northern Afar, extending at $\sim 12 \mathrm{~mm} / \mathrm{yr}$, due to spreading between the Nubia Plate and the Danakil Microplate (Fig. 1b) [Manighetti et al., 1998; McClusky et al., 2010]. The axis of Erta Ale Range, where tectonic and volcanic activity focus (Fig. 7a), shows active fracturing and predominant basaltic volcanism. The Erta Ale volcano lies along the Erta Ale Range axis and consists of a basaltic shield rising $\sim 700 \mathrm{~m}$ above the surrounding plain, with an elliptical caldera [Fig. 7b; Barberi and Varet, 1970; Barberi et al., 1973; Oppenheimer and Francis, 1998; Acocella, 2006].

Erta Ale has two focused rift zones, or fissure swarms, radiating North and South of the caldera (Fig. 7c and d). Each of these includes several eruptive fissures and vents, and has been more active than the previously described fissure swarms, each characterized by one 
or two rifting events (Acocella, 2006). However, being focused, these fissure swarms may represent an intermediate case between the immature fissure swarms of section 4.1 and the mature fissure swarms of section 4.2 and, as such, they are included here. The North Rift of Erta Ale consists of a $\sim 300 \mathrm{~m}$ wide and $\sim \mathrm{N}-\mathrm{S}$ trending fissure swarm, locally buried by recent lava flows; it is made up of segments of subparallel extension fractures and, subordinately, minor normal faults (Fig. 7c). The extension fractures have variable lengths and opening widths of typically up to several hundreds of meters and a few meters, respectively. The few normal faults are usually $<1 \mathrm{~km}$ long, with a vertical displacement $<2$ meters. The most accessible fault tip recognized is an OPF type (Fig. 7e). The South Rift is a $\sim$ NNW-SSE trending fissure swarm, <300 m wide, which is partly buried by more recent lava flows; it consists only of segments of subparallel extensional fractures, close in location and orientation to basaltic fissure eruptions formed by several vents aligned $~ N N W-S S E$ (Fig. 7d). The extension fractures have a variable length and opening width, which are usually up to $1 \mathrm{~km}$ and a few meters, respectively. No normal faults are found along the South Rift up to a distance of $2 \mathrm{~km}$ from the caldera. A significant part of the observed deformation along both fissure swarms may be due to the lateral emplacement of dikes from the caldera (dominant volcano) towards the lower slopes of the edifice [Acocella, 2006].

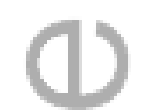

\subsection{Mature fissure swarms}

\subsubsection{Krafla (Iceland)}

The $80 \mathrm{~km}$ long and up to $10 \mathrm{~km}$ wide Krafla magmatic system and the associated fissure swarms strike NNE-SSW from Lake Myvatn to the North coast of Axarfjordur, undergoing a mean extension rate of 23 mm/yr (Fig. 8a) [Bjornsson et al., 1977; Perlt et al., 2008]. In its central portion, it hosts the $\sim 9 \mathrm{~km}$ wide active Krafla caldera, from where most of the 35 Holocene eruptions of the Krafla magmatic system occurred (Fig. 8a) [Bjornsson et al., 1977]. These eruptions included several rifting episodes: the 1.5-2 ka old basaltic fissure eruptions in Kelduhverfi and spatter cones at Gjastykki, the 1724-1729 AD Myvatn fires and the most recent rifting episode in 1975-1984 AD [Opheim and Gudmundsson, 1989]. During 
the latter episode, approximately 20 successive dike intrusions occurred, producing and reactivating fractures and normal faults [Bjornsson et al., 1977; Tryggvason, 1980; Einarsson, 1991]. Aerial imagery and leveling analyses indicate a maximum widening of $\sim 9$ $\mathrm{m}$ in the area of the eruptive fissure located 10-12 km North to the caldera [Tryggvason, 1994; Buck et al., 2006, Hollingsworth et al., 2012]. Leveling data focused on two diking events also indicate that each caused $0.5-1 \mathrm{~m}$ of subsidence above the dike and $\geq 0.5 \mathrm{~m}$ of uplift to its sides, decreasing with distance from the dike [Rubin and Pollard, 1988; Rubin, 1992]. About ten years after the end of the rifting episode, the post rifting deformation still consists of several $\mathrm{cm}$ of horizontal opening and $>10 \mathrm{~cm}$ of regional vertical uplift, much larger than the inter-rifting values [Hofton and Foulger, 1996].

Here we focus on the cumulative surface displacement of the fissure swarms, as produced on the longer-term $\left(10^{2}-10^{5}\right.$ years) by normal faults and extension fractures dissecting lava flows. The southern part of the northern fissure swarm is not formed by a simple graben; rather, there is a 2-3 km wide deformation zone with several extension fractures and normal faults within, defining 30-300 $\mathrm{m}$ wide minor nested graben (Fig. 8f). The mean strike of the faults is $\mathrm{N}^{\circ}$, similar to the $\mathrm{N} 12^{\circ}$ of the extension fractures (Fig. 8b). The graben border faults are usually vertical at the surface with a tensile area between the footwall and the hanging wall; the largest fault, defining the western rim of the 2-3 km wide central graben, has a maximum throw of $42 \mathrm{~m}$ and maximum width of 28 [Opheim and Gudmundsson, 1989; Angelier et al., 1997]. The average fault throw of the border faults in the considered portion of the swarm (Fig. 8) is $5 \mathrm{~m}$; the width of the tensile area between the footwall and the hanging wall of the faults is commonly $\sim 3 \mathrm{~m}$, locally reaching $5 \mathrm{~m}$ (Fig. 8 e). The opening of the extension fractures is usually $<1 \mathrm{~m}$ (Fig. 8e), smaller than the mean width of the tensile area of the normal faults. Most extension fractures at Krafla, even with opening of a few $\mathrm{m}$, are found on a flat surface. The footwall of the normal faults is usually subhorizontal, whereas the hanging wall may be subhorizontal or $20^{\circ}-30^{\circ}$ inward tilted and locally separated in different collapsed blocks (Fig. 8d, h, i). Contractional structures are found at the base of the tilted hanging wall of the normal faults in two places: $\sim 8 \mathrm{~km}$ North to the caldera rim and at the southern tip of the southern fissure swarm (Fig. 8a). The latter is along the $2 \mathrm{~km}$ long Grjotagja fault, in the Myvatn area, on the western boundary of a $\sim 1 \mathrm{~km}$ 
wide graben on a $\sim 2.7$ ka lava flow. Here the fault strikes $N 355^{\circ}$ and displays $5-6 \mathrm{~m}$ of vertical throw, with a titled hanging wall of $30-35^{\circ}$, separated from the footwall by a $2 \mathrm{~m}$ open fracture (Fig. 8i, I). The well-exposed base of the tilted hanging wall consists of a strip parallel to the fault trace, $10^{2} \mathrm{~m}$ long, of folded and at times chaotic lava blocks, indicating localized contraction. The best exposures systematically reveal a tight cylindrical fold, $\sim 1 \mathrm{~m}$ wide and with an $\sim 90^{\circ}$ interlimb angle, whose axis is parallel to the fault (Fig. $8 \mathrm{~m}$ ). The associated contraction of the fold is $7-20 \%$ of the horizontal extension [Trippanera et al., 2014]. A similar contraction at the base of the tilted hanging wall is found on a fault to the North of Grjotagja (Fig. 8a, 9) and on another fault North of Krafla caldera (Fig. 8a). Along the Krafla fissure swarm, $95 \%$ of the observed fault tips (that is 18 out of 19) terminate as open fractures without any hanging wall tilt, or as OPF type (Table 1, Fig. 8g; Fig. 9).

\subsubsection{Vogar (Iceland)}

The $10 \mathrm{~km}$ long Vogar fissure swarm lies in the northern portion of the $35 \mathrm{~km}$ long and 5$8 \mathrm{~km}$ wide Reykjanes fissure swarm, in southern Iceland (Fig. 10a, b) [Gudmundsson, 1980; Villemin and Bergerat, 2013; Clifton and Kattenhorn, 2006]. The amount of pure extension in this highly oblique portion of rift is $\sim 6 \mathrm{~mm} / \mathrm{yr}$ [Keiding et al., 2008]. The Vogar fissure swarm consists of a 3-4.5 km wide asymmetric deformation zone delimited on the western edge by an East facing normal fault (Hrafnagjá) and on the eastern edge by a series of open fissures (Grindavikurgjá) [Villemin and Bergerat, 2013]. An inner graben hosts five major West-facing normal faults, vertical at the surface and with a dilational component between the footwall and hanging wall. The footwall is subhorizontal and the hanging wall varies from subhorizontal to tilted $\left(\sim 30^{\circ}\right)$. The mean fault throw and width of the tensile area are $\sim 2 \mathrm{~m}$ and $\sim 1 \mathrm{~m}$, respectively, both reaching a maximum $>10 \mathrm{~m}$. Similar to Krafla, at Vogar there is contraction at the base of the tilted hanging wall of normal faults with vertical throw of a few meters bordering a $\sim 20 \mathrm{~m}$ wide graben. Here the tilted lavas of the hanging wall abruptly terminate above the horizontal lavas of the inner graben, indicating the presence of a thrust or reverse fault, rather than folds, as in Krafla (Fig. 10e, f). Most extension fractures at Vogar, even with opening of a few $\mathrm{m}$, are found on a flat surface. Field measurements show that 35 out of 42 lateral tips of the normal fault are tilted, forming 
a monocline and suggesting the presence of FPF types; the remaining 7 faults terminate as open fractures in a flat topography area, suggesting OPF types (Fig. 10c, d) [Norini et al., 2009]. These results are broadly consistent with previous ones [Grant and Kattenhorn, 2004], which show that beyond their lateral tips, the normal faults continue as narrow monoclines and/or clusters of tension fractures.

\subsubsection{Thingvellir (Iceland)}

The $10-20 \mathrm{~km}$ wide NE-SW trending Thingvellir fissure swarm belongs to the $>60 \mathrm{~km}$ long Pleistocene Hengill magmatic system and lies North to the Lake Thingvallavatn in Iceland (Fig. 10a, 11a). Similarly to Vogar, the extension rate is low [5 mm/yr; Perlt et al., 2008]. The inner part of the fissure swarm consists of a $\sim 5 \mathrm{~km}$ wide graben delimited by several inward dipping conjugate normal faults dissecting basaltic lavas flows, pillow lavas and lake sediments >1.9 ka [Gudmundsson, 1987; Bull et al., 2005]. The graben has been affected by up to $40 \mathrm{~m}$ of subsidence and $70 \mathrm{~m}$ of horizontal extension in the last $9 \mathrm{ka}$ [Saemundsson, 1992].

Most of the border faults in Thingvellir show a typical dilational component, with flat footwall and tilted hanging wall. The vertical throws of the major faults are on the order of few tens of meters, locally reaching $30-35 \mathrm{~m}$. This is the case of the $7.7 \mathrm{~km}$ long Almannagja fault, forming the eastern graben border, and the $11 \mathrm{~km}$ long Hrafnagja fault, forming the western border (Fig. 11b, c) [Gudmundsson, 1987; Saemundsson, 1992; Bull et

al., 2005; Sonnette et al., 2010]. Thingvellir also shows smaller Holocene normal faults with both flat footwall and hanging wall. Many extension fractures, even with opening of a few $\mathrm{m}$, are found on a flat surface. Field measurements at Thingvellir show that 22 out of the 26 observed lateral terminations of the normal faults are tilted, suggesting a FPF type: among these is the southern termination of the large Almannagja Fault, bordering the western portion of the innermost graben (Fig. 11d, e); conversely, only 4 terminations show a flat footwall and hanging wall, resembling a OPF type [Norini et al., 2009].

\subsubsection{Manda Hararo (Ethiopia)}


The Manda Hararo magmatic system constitutes the southern portion of the NW-SE trending Red Sea Rift of Afar (Fig. 1b). The considered portion of the southern fissure swarm lies within the axial zone of the Tendaho Graben, the largest extensional structure in the transitional crust of Central Afar, with an estimated extension between 1 (geologic estimate for the last $0.2 \mathrm{Ma}$ ) and $15 \mathrm{~mm} / \mathrm{yr}$ (geodetic estimate) [Acocella et al., 2008; McClusky et al., 2010]. This portion of the Manda Hararo Rift consists of a basaltic plateau, surrounded by sedimentary and subordinate volcanic deposits (Fig. 12a). While the plateau is highly fractured, with fault scarps reaching several meters of vertical displacement, the surrounding deposits are not faulted or fractured.

The axial portion of the fissure swarm is characterized by an overall horizontal attitude of the basalts. If the basalts are tilted, this typically occurs in the immediate hanging wall of open normal faults, and decreases in importance a few $\mathrm{m}$ from the fault (Fig. 12b). The faults often form opposite-facing scarps, between $\sim 1$ to $\sim 10 \mathrm{~m}$ high, arranged in an overall graben-like fashion. Each graben is a few $\mathrm{km}$ long and several hundreds of meters to 1-2 $\mathrm{km}$ wide. The alternation of horst and graben is the most recurrent structural style along the fissure swarm [Acocella et al., 2008]. The three most accessible normal fault tips, on the southern part of the studied area, are all OPF types (Fig. 12c and d). Extension fractures, up to a few hundreds of $\mathrm{m}$ long and a few $\mathrm{m}$ wide, are subordinate and usually found within the graben (Fig. 12a).

\subsubsection{Fantale (Ethiopia)}

The Fantale magmatic system lies in the central portion of the continental Main Ethiopian Rift (MER), Ethiopia, where the mean extension rate is $\sim 7 \mathrm{~mm} / \mathrm{yr}$ [Fernandes et al., 2004]. From a structural point of view, this area is probably the most representative of the MER, as it hosts recent and well-preserved fissure swarm, largely to the south of Fantale caldera. The last historical eruption, producing a lava field and a series of $\mathrm{N} 25^{\circ}$ aligned cinder and spatter cones, occurred in 1820 AD to the South of the caldera [Williams et al., 2004]. The southern fissure swarm has an overall NNE-SSW orientation and is characterized by extension fractures and normal faults that dissect $168 \pm 38$ ka welded tuff originating from the 
Fantale caldera [Williams et al., 2004]. The fissure swarm, developed during the last $7 \mathrm{ka}$, focuses in a $3 \mathrm{~km}$ wide and $15 \mathrm{~km}$ long area [Williams et al., 2004].

The field survey is carried out across a principal graben structure along the southern fissure swarm. The $2.5 \mathrm{~km}$ wide graben is delimited by two main inward dipping normal border faults oriented $\mathrm{N} 24^{\circ} \pm 12^{\circ}$ (Fig. 13b). The faults show a constant dilational component of a few meters between the footwall and the hanging wall (Fig. 13e, 13g). The throw on the border faults reaches 10-15 $\mathrm{m}$ on the western and 15-20 $\mathrm{m}$ on the eastern border. The mean tilt of the hanging wall is of $30^{\circ} \pm 10^{\circ}$, but locally up to $88^{\circ}$ (Fig. 13C). Similarly to Krafla and Vogar, local contraction structures parallel to the fault strike have been observed in the central graben (Fig. 13d) [Trippanera et al., 2014]. Several extension fractures with an opening of 1-2 $\mathrm{m}$ are present within the graben (Fig. 13f). Analysis of the terminations of the principal faults reveals that 14 out of 26 tips have a tilted hanging wall, suggesting a FPF type, whereas 12 fault terminations show an OPF type. Most of the FPF types of termination (10 cases) are located along the border faults. Conversely, most of the OPF type of termination (11 cases) are located inside the graben. To the North of Fantale, sparse border faults have poor accessibility, due to dense vegetation. We generally observed similar structures: extension fractures and dilational normal faults with tilted hanging wall.

\section{5 - Discussion}

\section{1 - General structural features of normal faults along fissure swarms}

All the studied areas, independent of the nature of the crust (oceanic, transitional or continental) and the amount of extension, display an overall similar deformation pattern: eruptive fissures, extension fractures and normal faults. Normal faults usually form grabenlike structures hosting eruptive fissures. In the case of immature fissure swarms (Laki, Eldgja, Sveinagja, Sveinar; section 4.1), the graben are narrow (1 km or less) and usually symmetric. In the case of the mature fissure swarms (Krafla, Vogar, Thingvellir, Manda Hararo, Fantale; section 4.2), the 2-20 km wide graben show some degree of asymmetry, hosting smaller and nested graben with a distributed fracture network. The structure of the normal faults bounding the graben may vary along the immature and mature fissure swarm: the most common types of shallow fault structure, in section view, are summarized in Fig. 
14. The differences in the fault types are related to the structure of the tensile portion of the fault between the footwall and the hanging wall, as well as the tilt of the latter. In addition, where the material at the surface is poorly consolidated or weak, it may be easily eroded and, as a result, the morphology of the fault may be poorly defined. Therefore, the vertical throw of the fault may be underestimated and the dilational component may be partly buried by the colluvium (Fig. 14). For example the Lakagigar graben faults, are not always well visible on flat areas filled by loose eruptive products. On the contrary, faults and fractures are well exposed on the Laki hill, made of consolidated, and therefore stiffer, hyaloclastite The Laki case provides an example of how the host rock composition may affect the morphology and the structure of the normal faults, consistent with results from numerical models [Hardy, 2013].

There is an overall direct relationship between the vertical throw of the normal faults and their dilational component, suggesting that the increase of vertical displacement is also related to the increase of the extension (Fig. 15a). Also, the Icelandic data have a lower dilational component, focusing on the left part of the diagram. In addition, the amount of tilt of the hanging wall shows, despite some scatter, an overall direct relationship with the throw (Fig 15b) and the dilation (Fig. 15c) of the normal faults; the latter relationship is particularly evident for the MER faults. The scatter in the hanging wall tilt reflects the at times significant variability of the tilt measured along a same fault. In fact, within a distance of very few tens of meters, where the dilation and throw of a fault remain constant, the tilt may vary dramatically, from $22^{\circ}$ to $65^{\circ}$ or more (i.e. Sveinar or in Fantale). This feature suggests that this tilt is partly independent of the amount of displacement of the normal fault.

The tilt of the hanging wall may be related to the variation in friction along the fault plane at depth, in turn also related to the presence of asperities; a higher friction at depth would hinder the displacement of the hanging wall next to the fault plane, resulting in a higher tilt of the hanging wall at the surface, whereas a lower friction would result in a flat hanging wall. It is expected that, decreasing the amount of friction along the fault through its activity, tilted hanging walls evolve into subhorizontal hanging walls [e.g. Martel and Langley, 2006]. However, faults with displacement of several tens of meters do still show a significant hanging wall tilt, as at Thingvellir, suggesting that fault maturity alone cannot explain the tilt. 
Recent analogue models of deformation due to dike emplacement may partly explain the tilt of the hanging wall of large faults; the hanging wall tilt observed above intruded dikes may be related to the presence of an upward propagating high angle normal fault reversing its plunge (and thus becoming reverse) while approaching the free surface [Trippanera et al., 2014]. Therefore, analogue models suggest that, dikes explain the tilted hanging wall shown by some faults in nature. A further possibility to explain the tilt of the hanging wall of mature faults is their upward propagation during reactivation.

\section{2 - The growth of faults accompanying immature fissure swarms}

The deformation pattern associated with the emplacement of dikes feeding the eruptive fissures "along immature fissure swarms (Laki, Eldgja, Sveinagja, Sveinar; section 4.1) is represented by a set of conjugate normal faults, usually to the sides of the fissure resulting in a graben, 0.16 to $1.7 \mathrm{~km}$ wide (Table 1). A rifting episode may generate up to $5 \mathrm{~m}$ of vertical displacement, as at Lakagigar in 1783, or even more, as possibly at Eldgja and Sveinar. These throws are larger than those previously measured, <2-3 $\mathrm{m}$, in other major rifting episodes as in Krafla in 1975-1984, Dabbahu in 2005, and rifting events such as at Dallol in 2004 and Harrat Lunayyir in 2009 [Sigurdsson, 1980; Rubin and Pollard, 1988; Rowland et al., 2007; Pallister et al., 2010; Nobile et al., 2012].

In addition to field observations, experimental, analytical and numerical models have shown that the emplacement of a shallow dike feeding an eruptive fissure may generate a set of conjugate normal faults, resulting in a graben at the surface [Mastin and Pollard, 1988; Rubin and Pollard, 1988; Rubin, 1992; Gudmundsson, 2003; Gudmundsson, 2005]. The studies linking normal faulting at the surface to dike emplacement at depth assume that the faults propagated upward from the upper tip of the dike [Grant and Kattenhorn, 2004; Tentler, 2005; Rowland et al., 2007]. This implies that the lateral terminations of the normal faults should show a fault propagation fold-like structure. Conversely, field analysis of the tips of the normal faults related to the development of three immature fissure swarms (Lakagigar, Sveinagja, Sveinar) shows an OPF type of termination, suggesting downward fault propagation during dike emplacement (Fig. 16a, b, c). In the remaining immature 
swarm (Eldgja NE), the faults terminate laterally developing fault propagation folds-like structures, suggesting upward propagation (Table 1).

Even though the at times widely variable amount of tilt of the hanging wall in the central part of the fault is poorly informative of its kinematics, the tilt of the hanging wall at the lateral termination of the fault can be used to infer the possible sense of propagation of the fault [e.g. Cartwright and Mansfield, 1998]. The latter tilt allows us to detect the very early stage mechanism of development of the fault structure, immediately before the fault forms, at the lateral tip of the precursory extension fracture [Gudmundsson, 1992; Acocella et al., 2003; Grant and Kattenhorn, 2004]. At this early stage, the presence or absence of the tilt of the hanging wall reflects the upward or downward direction of propagation of the fault, respectively. Therefore, the available data from the immature fissure swarms suggest that most faults related to the emplacement of the dikes have propagated from the surface downwards, conversely to previously inferred [e.g. Tentler, 2005, Rowland et al., 2007].

Our analysis provides a new perspective to interpret the origin of faults along the axial part of fissure swarms, bypassing the dichotomy illustrated in the introduction, with downward propagating normal faults commonly considered tectonically-induced and upward propagating faults magma-induced. Rather, our observations suggest a more complex fault propagation mechanism, where downward propagating faults are dike-induced. This result is consistent with new experiments of dike-induced faulting [Trippanera et al., 2015], where the normal faults formed during the emplacement of a dike complex systematically develop at the surface and propagate downward. These experiments, coupled with numerical models [Trippanera et al., 2015], show that the nucleation of the normal faults and their downward propagation result from the presence of a free-surface, where the lithostatic load is least [Trippanera et al., 2015]. These results are also consistent with previous models of fault formation along divergent plate boundaries, where a normal fault results from the growth of an extension fracture at the surface, once the latter reaches a critical depth when the lithostatic load imposes a shear stress on the fracture plane [Forslund and Gudmundsson, 1992; Gudmundsson, 1992; Acocella et al., 2003].

The narrow graben, $\sim 1 \mathrm{~km}$ wide or less, associated with the dikes feeding the studied eruptive fissures along immature fissure swarms also imply a shallow depth $(<1 \mathrm{~km})$ of the 
dike at the moment of the nucleation of the normal faults. Considering a commonly observed dip of $\sim 70^{\circ}$ of the normal faults in the eroded portions of Iceland [Gudmundsson, 1992], also in agreement with our normal fault dip observations (with values from $70^{\circ}$ to $80^{\circ}$; see Fig. 4), these graben likely formed when the upper tip of the dike was shallower than 1.5-2 km. However, in some cases (Lakagigar, Eldgja Central) a mean width of 200-300 m of the graben suggests a much shallower depth to the top of the dike for the nucleation of the normal faults, in the order of 500-700 m or less.

The fissure swarms of Erta Ale provide further insights on the possible relationships between surface deformation and diking: their narrowness (usually 150-200 m wide), the overall lack of normal faults, the dominance of distributed extension fractures associated with the vents feeding the fissure eruptions suggest a formation through very shallow (few hundreds of meters) dikes. In fact, a model of vertical propagation of dikes implies a much broader area of deformation, with normal faults bordering $\mathrm{km}$-wide graben-like structures. Conversely, a model of lateral propagation of shallow dikes departing downslope from the dominant volcano summit, where the magmatic conduit has been constantly opened and degassed for a century at least, best fits these observations. This is in agreement with previous studies [Acocella, 2006], as well as similar deformation patterns observed on volcanic rift zones elsewhere, i.e. Etna [Acocella and Neri, 2003]. Therefore, the narrow fissure swarms of Erta Ale are the expression of repeated and shallow lateral dike propagation from a central volcanic edifice with open conduit. This process is a scaled-down and shallower analogue of the recently observed much larger (up to $60 \mathrm{~km}$ long) and deeper (up to $9 \mathrm{~km}$ ) lateral propagations of dikes along the axis of rifts, as at Dabbahu.

The structural analysis of the faults along dike-induced immature fissure swarms and their inferred downward mode of propagation suggest how faults form and grow during diking events and episodes. This information is used in the next section as a reference to better understand the longer-term growth of the normal faults along the more complex mature fissure swarms, which may be in principle not only related to the above mentioned diking events and episodes, but also to any amagmatic faulting.

\section{3 - The growth of faults accompanying mature fissure swarms}


The structure of the mature fissure swarms observed at Krafla, Vogar, Thingvellir, Manda Hararo and Fantale consist of an overall repetition of the structural features found along the immature fissure swarms. The mature fissure swarms are, however, characterized by a wider graben-like structure (as at Thingvellir), often showing secondary structures or graben within (as at Fantale or Krafla). Alternatively, the mature fissure swarms may consist of juxtaposed and nested graben systems along a much wider and less symmetric area than that of the single eruptive fissures (as at Vogar and Manda Hararo). Despite repetitions and asymmetries, the basic graben-like scheme found along the immature fissure swarms is also present in the considered mature fissure swarms; in addition, the structural features, size and displacements of the normal faults and the extension fractures are remarkably similar in both the immature and mature fissures swarms. These structural similarities suggest overall common mechanisms in their development of both fissure swarm types. In synthesis, the collected data along MDPB show that the simple structural scheme given by graben-like structures with open normal faults and displacement up to $\sim 10 \mathrm{~m}$ observed along immature fissure swarms is found, with asymmetries and repetitions, also within mature fissure swarms.

In addition, the OPF and the FPF types of fault terminations are both found along immature and mature fissure swarms. However, while the OPF type dominates in faults at the sides of eruptive fissures along immature fissure swarms, the mature fissure swarms show a predominance of FPF types, with the exception of the more extended Krafla case. More in detail, the measured FPF types of fault tips predominate along the mature fissure swarms, and near double the OPF types, being 72 against 41 (Table 1). According to what introduced in the Methodology section [Cartwright and Mansfield, 1998], this FPF type of fault termination suggests an upward propagation of the normal faults, towards the surface. Conversely, a lateral termination of the normal faults as OPF type is supported by the data collected along Krafla and, to a minor extent, along the Manda Hararo, Fantale, Thingvellir and Vogar (Table 1). This suggests that an important part of the normal faults along wider and more complex mature fissure swarms may still form though downward propagation from the surface. 
The OPF type of fault tip is supported by modeling evidence [Trippanera et al., 2015], suggesting that this is a feasible mechanism of development of normal faults along divergent plate boundaries. These faults, despite their downward propagation, result from dike emplacement. The FPF type of fault tip is not supported by modeling results [Trippanera et al., 2015] and more challenging to explain. A possible explanation is related to the reactivation of pre-existing buried normal faults below volcanic deposits: when a buried fault is reactivated, it propagates upward from the base of the overlying unfaulted deposit. Many faults along divergent plate boundaries are reactivated during magmatic and/or tectonic events, because the fault reactivation process often requires the least energy for extension than any new fault nucleation [i.e. Rowland et al., 2007; Nobile et al., 2012; sigmundsson et al., 2015]. Volcanic products along fissure swarms may easily bury faults and extension fractures at the surface. With given erosion and uplift rates, the production of burial deposits and the duration of the burial may depend, in addition to the frequency and type of volcanic activity, on the extension rate of the rift segment: the lower the extension rate, the more effective may be the possibility to bury a fault, and for a longer period. Any reactivation induces slip along a pre-existing fault, or portion of; if the slip reaches the periphery of the fault, then the fault propagates. Along buried normal faults, if the uppermost portion of the reactivated fault carries most of the slip, the fault will propagate towards the surface. Therefore, the reactivation of pre-existing normal faults may induce an upward propagation, through the deposits above the fault, developing a FPF type of fault tip (Fig. 16d, e, f), A similar process, highlighting the relationships between fault propagation and resurfacing by lava flows, has been previously described to explain the geometric and kinematic features of the Koa'e Fault System on Kilauea volcano, Hawaii [Podolsky and Roberts, 2008]. The proposed mechanism may also explain the higher frequency of the FPF types of fault tip in the less extending fissure swarms (Table 1), where fault activity is slower and the faults may be and remain more easily buried. In a similar fashion, despite the limited amount of data and any uncertainty on the extension rate estimates, on the fissure swarms there may be also a proportion between the frequency of the OPF types of fault termination and the extension rate of the swarm (Table 1). This is also supported by the fact that the only FPF type of fault tip at the faster extending rift of Krafla has been found at the 
less active termination of the southern fissure swarm (Grjotadgja), where the extension rate appears lower [Brandsdóttir et al., 1997].

Even if a reactivated normal fault has been propagating upward towards the surface, developing a fault propagation fold, our collected data, as well as modeling results and field studies, suggest that in general the normal faults primarily nucleate from the surface and propagate downwards [Gudmundsson, 1992; Acocella et al., 2003; Trippanera et al., $2014 b]$. Conversely to previous studies directly relating normal faulting to regional extension (Gudmundsson, 1992; Acocella et al., 2003), our data suggest that, neglecting any reactivation, any normal fault along divergent plate boundaries may propagate downward during diking. This is evident in the case of the narrow graben containing all the eruptive fissures (in immature fissure swarms), where the common downward propagating normal faults result from the emplacement of the dikes feeding the fissure. The possibility of a magmatic origin for the normal faults is likely in the case of mature fissure swarms with higher spreading rate, consisting of a major, more or less symmetric graben-like structure with nested graben within, where OPF types of fault tip predominate, as at Krafla. These OPF types may be well reconciled with the downward propagation of normal faults induced by diking. The possibility of a magmatic origin for the normal faults is also likely in the case of fissure swarms with lower spreading rate, characterized by dominant FPF types of fault termination, interpreted as resulting from fault reactivation; in this case, the same faults should have formed propagating downward during diking episodes and reactivated during subsequent diking episodes.

In synthesis, the structural features of the normal faults along the axis of mature fissure swarms are similar to, even though repeating, those of the faults associated with immature fissure swarms. However, many normal faults propagate not only downward (as for those dike-induced), but also upward, as seems to be the case for fault burial and reactivation along slower spreading fissure swarms.

\section{4 - A general model for magmatic divergent plate boundaries}

The collected data allow us to better understand how faults grow along the axis of MDPB, in turn helping constraining any contribute of magmatism (diking) or amagmatic faulting 
(regional tectonics). In particular, our data a) highlight the importance of the dikes feeding eruptive fissures in creating surface deformation and b) suggest that diking may also explain most of, perhaps all, the structure of the fissure swarms developed at the surface within a time span of $10^{2}-10^{5}$ years. To insert this information in a broader temporal perspective, we consider what happens during the entire life time of a magmatic system ( $10^{4}$ years or more) from deeper crustal sections and summarize available geodetic data (last decades), to better capture any transient behavior.

We first consider available data from the deeper portions of the fissure swarm, as outcropping on the eroded magmatic systems in eastern Iceland. Here, at a paleodepth of 1-2 km, the magmatic systems consist of dike swarms $50 \mathrm{~km}$ long and 5-10 km wide [Walker,"1958; 1960; Gudmundsson, 1983; 1995]. We consider the well-exposed and wellstudied Alftafjordur paleo-magmatic system to constrain the mean number of dikes possibly constituting a dike swarm and any variation in their frequency with the distance from the dominant volcano. To this aim, we trace five profiles across different portions of the dike swarm, using our own new dataset and published data (Fig. 17) [Gudmundsson, 1990; Paquet et al., 2007]. Of the considered sections, A and B do not cover the entire width of the swarm, that is partly below the sea level; therefore, we extrapolate the possible number of dikes across the entire width of the swarm from their frequency in the inland portion of the profiles. The comparison among the five profiles shows that there is not a significant variation in the dike frequency across the swarm with the distance from the dominant volcano (Fig. 17b), with a mean frequency of $100 \pm 20$ dikes at a paleodepth of $\sim 1.5 \mathrm{~km}$.

In the eroded fissure swarms of Iceland, the frequency of the observed dikes is highest at the sea level and decreases upwards (towards the paleo-surface), suggesting that most dikes do not propagate upward and taper away towards their paleosurface [Walker, 1960; Gudmundsson, 1983]. In order to have rough estimate the percentage of dikes reaching the paleosurface, we plot the variation of the frequency of the dikes with their present altitude (the inverse of the paleodepth) using data from Alftafjordur [Walker, 1960] and Reydarfjordur [Walker, 1958] in Eastern Iceland and from NW Iceland [Gudmundsson, 1984]. Despite the considerable scatter of the data, only a fraction (<20\%) of the dikes found at $\sim 1.5 \mathrm{~km}$ of depth within a magmatic system reaches an altitude of $1 \mathrm{~km}$ above sea 
level, corresponding to a paleodepth of $\sim 0.5 \mathrm{~km}$ (Fig. 18). Therefore, if the $100 \pm 20$ dikes found at Alftafjordur are representative, as order of magnitude, of the frequency of the dikes currently at a paleodepth of $\sim 1.5 \mathrm{~km}$ below the active rifts of Iceland, only a very few tens of dikes are expected to reach shallow levels ( $\sim 0.5 \mathrm{~km}$ depth) in a magmatic system.

The possible effect of these very few tens of dikes on the surface deformation pattern is considered below. At a depth of $\sim 0.5 \mathrm{~km}$ any propagating dike induces anelastic surface deformation (see section 5.1), activating or reactivating normal faults at the surface. The mean vertical slip commonly observed on normal faults at the surface during different recent diking events and episodes is shown in Fig. 19 as a function of the inferred depth and thickness of the dike. Despite the scatter, there is an overall increase in the slip of the fault with the thickness of the dike and its shallowness. This implies that shallower and thicker dikes induce larger slip on the normal faults at the surface. In any case, the observed slip on the faults is on the order of 1 and $3 \mathrm{~m}$ (Fig. 19). This confirms that each diking event or episode may be, in general, responsible for vertical slip of a few meters along a pair of conjugate normal faults.

Assuming that 10-20 dikes may reach the uppermost $0.5 \mathrm{~km}$ of depth in the active portion of a fissure swarm (Fig. 18), it is expectable a cumulative amount of vertical deformation at the surface between $10 \mathrm{~m}$ (assuming the lower bound of the mean slip value of $1 \mathrm{~m}$ for 10 dikes) and $60 \mathrm{~m}$ (assuming the upper bound of the mean slip value of $3 \mathrm{~m}$ for 20 dikes). These values may explain the common vertical displacements, carried either along a few major faults or several minor faults, currently observed at the surface along the active portions of mature fissure swarms, as at Krafla, Thingvellir, Vogar and Fantale. However, since eruptive fissures along immature fissure swarm, as observed at Lakagigar or Sveinar, may induce surface faulting with vertical slip of 5 meters or more (Fig. 3e), even very few shallow dikes may explain the large surface deformation observed along active mature fissure swarm, as at Krafla.

Then, the available geodetic studies to detect transient behavior along the axis of MDPB are considered. In some cases, as along the currently volcanically inactive Reykjanes Peninsula, the geodetic extension varies from zero (between 1993-1998) up to $\sim 7 \mathrm{~mm} / \mathrm{yr}$ (between 2000-2006) (Hreinsdottir et al., 2001; Keiding et al., 2008). Similar variations have 
been obtained for the MER, where geodetic measurements between 1976 and 1992 suggest a widening rate of $\sim 1.1 \pm 2.2 \mathrm{~mm} / \mathrm{yr}$ (Asfaw et al., 1992), between 1969 and 1997 indicate an extension of $4.5 \pm 1 \mathrm{~mm} / \mathrm{yr}$ (Bilham et al., 1999) and between 1992 and 2010 highlight an extension of $8 \mathrm{~mm} / \mathrm{yr}$ (Kogan et al., 2012): compared to the 1976-1992 measurements, the higher 1969-1997 extension rate may have been affected by the postemplacement relaxation of a dike in the central MER in 1993 (Bendick et al., 2006). In general, the variability of these data, coupled with extension rates at times significantly lower than the predicted ones and the absence of amagmatic faulting, suggests a limited role of regional tectonics in maintaining the extension along temporarily inactive magmatic systems.

In other cases, fault slip of up to a few cm/yr has been detected. Between 1997 and 2005, the aseismic behaviour of faults related to bursts of micro-seismicity was accompanied by slip on three main active faults the Asal Rift (Afar); fault slip occurred both as steady creep and during sudden slip events, accompanied by an increase in the seismicity rate around Fieale volcano (Doubre and Peltzer, 2007). The extension rate across the rift exceeding the far-field plate velocity indicated that the magmatic system under the rift and the volcano was over-pressurized, and therefore prone to force fluids into shallower fractures, triggering earthquakes and minor fault slip (Doubre and Peltzer, 2007). While this case testifies fault slip not coeval to diking, the role of magmatism in deforming the surface should not be neglected; this is underlined by the overpressurization of the magmatic system beneath Fieale (Doubre and Peltzer, 2007), the overall geometry of faulting and topography at the Asal Rift, related to longer-term diking intrusions at depth (Pinzuti et al., 2010) and, not least, the overall post-diking crustal relaxation following the 1978 Asal-Ghoubbet rifting episode (Vigny et al., 2007). At both the Asal and Krafla fissure swarms, steady extension along the axis of the rift has been geodetically detected. This extension, slightly higher than that deduced from plate motion models, has been related to the decade-long post-rifting relaxation of the crust after the 1978 Asal-Ghoubbet and 19751984 Krafla rifting episodes, both dike-induced (Hofton and Foulger, 1996; Vigny et al., 2007; Arnadottir et al., 2009). 
These results suggest that shallow dike emplacement $(<0.5$ to $1 \mathrm{~km})$ may explain most, if not all, the observed deformation along the considered fissure swarms, so that the overall shape, structure and development of the considered divergent plate boundaries may be in principle entirely magma-induced. Regional tectonics, in the form of ridge push and constant strain accumulation at the plate boundary, certainly plays a fundamental preparatory role: it promotes the required long-term strain along the plate boundary to accommodate parallel dikes; the latter, in turn, generates the structures observed along fissure swarms. Regional tectonics may also directly activate normal faults, seismically or not, during inter-diking episodes. However, the collected data suggest that in these magmatically active rifts, where plate separation is constantly maintained by diking, the regional tectonic stress may rarely reach values high enough to be released and activate the normal faults. Therefore, any direct role of amagmatic faulting in separating and shaping these plate boundaries appears negligible compared to that of diking.

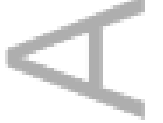

\section{6 - Conclusions}

We analyzed the structure and the sense of propagation of the normal faults to define the mechanisms of fault formation and growth, in turn constraining any contribute of magmatism (diking) or regional tectonics in shaping these rifts.

Eruptive fissures along immature fissure swarms are characterized by a single graben structure with open normal faults and vertical displacement of a few meters. Most faults terminate as open fractures on a flat surface, suggesting a downward fault propagation after nucleation at the surface. The lateral propagation of shallow dikes from a dominant volcano may also account for narrow fissure swarms, with poor normal faulting, as observed at Erta Ale.

A consistent graben-like structure is found, with asymmetries and repetitions, also within the mature fissure swarms of Iceland, Afar and the MER. Here the development of the normal faults may be influenced by the spreading rate. In faster extending fissure swarms ( $>1 \mathrm{~cm} / \mathrm{yr}$ ), normal faults usually terminate as open fractures on a flat surface, suggesting a downward propagation of the fault after surface nucleation. In slowly extending rift segments 
(<1 cm/yr), normal faults predominantly terminate as open fractures on a monocline, suggesting upward propagation after a deeper nucleation. Any upward propagation of normal faults observed in the field is largely related to fault reactivation due to dike emplacement after burial by volcanic or sedimentary deposits.

In general, the entire surface deformation pattern (i.e. extension fractures, normal faults, graben) of the fissure swarms observed along the axis of active divergent plate boundaries may be qualitatively explained by events or episodes of dike emplacement.

Simple calculations, based on the structure of the eroded rift portions of eastern and western Iceland, suggest that all the fault slip in the studied rift zones, reaching several tens of meters, results from repeated shallow dike intrusion. In addition, geodetic data reveal negligible or no fault slip outside the dominant volcanoes of the magmatic systems, including the fissure swarms recently affected by rifting events (in the inter-rifting periods).

In a magmatically active rift most, if not all, of the surface faulting (and thus graben formation) may be ascribed to diking, with limited role of amagmatic faulting (regional tectonics) in inducing fault slip.

\section{Acknowledgements}

Thor Thordarson and Gianluca Norini partly participated to the field analysis. Agust Gudmundsson provided helpful and stimulating discussions and inputs over so many years. Stefano Urbani helped in collecting the data in the Alftafjordur area. Asta Rut Hjartardottir provided helpful information on several areas in Iceland. Three anonymous reviewers, the Editor John Geissman and the Associate Editor John Cottle provided helpful reviews on an earlier version of the manuscript. Financed with PRIN 2009 funds (2009H37M59, responsible $\mathrm{V}$. Acocella). Any user can access the data of this work by contacting the corresponding author.

\section{References}

Acocella, V. (2006). Regional and local tectonics at Erta Ale caldera, Afar (Ethiopia). Journal of Structural Geology, 28, 1808-1820. 
Acocella, V. (2014). Structural control on magmatism along divergent and convergent plate boundaries: overview, model, problems. Earth-Science Reviews, 136, 226-288. Doi:10.1016/j.earscirev.2014.05.006

Acocella, V., and Korme, T. (2002). Holocene extension direction along the Main Ethiopian Rift, East Africa. Terra Nova 14, 191-197

Acocella, V., Korme, T., and Salvini, F. (2003). Formation of normal faults along the axial zone of the Ethiopian Rift. Journal of Structural Geology, 25, 503-513.

Acocella, V., and Neri, M. (2003). What makes flank eruptions? The 2001 Etna eruption and its possible triggering mechanisms. Bulletin of Volcanology, 65, 517-529. Doi: 10.1007/s00445-003-0280-3

Acocella, V., Abebe, B., Korme, T., and Barberi, F. (2008). Structure of Tendaho Graben and Manda Hararo Rift: implications for the evolution of the Red Sea propagator in Central Afar. Tectonics 27, TC4016. Doi: http://dx.doi.org/10.1029/2007TC002236.

Angelier, J., Bergerat, F., Dauteuil, O., and Villemin, T. (1997). Effective tension-shear relationships in extensional fissure swarms, axial rift zone of Northeastern Iceland. Journal of Structüral Geology, 19(5), 673-685. Doi: 10.1016/S0191-8141(96)00106-X

Angelier, J., Bergerat, F., Stefansson, R., and Bellou, M. (2008). Seismotectonics of a newly formed transform zone near a hotspot: earthquake mechanisms and regional stress in the South Iceland Seismic Zone. Tectonophysics, 447, 95-116.

Ayele, A., Jacques, E., Kassim, M., Kidane, T., Omar, A., Tait, S., Nercessian, A., de Chabalier, J.B., and King, G. (2007). The volcano-seismic crisis in Afar, Ethiopia, starting December 2005. Earth and Planetary Science Letters, 255, 177-187.

Barberi, F., and Varet, J. (1977). Volcanism of Afar: small-scale plate tectonics implications. Geological Society of America Bulletin, 88, 1251-1266.

Barberi, F., and Santacroce, R. (1980). The Afar Stratoid series and the magmatic evolution of East African Rift System. Bull. Soc. Geol. Fr., 7, 891-899.

Barberi, F., Tazieff, H., and Varet, J. (1972a). Volcanism in the Afar depression; its tectonic and magmatic significance. Tectonophysics 15, 19-29.

Barberi, F., and Varet, J. (1972b). Geological map of the Erta Ale volcanic range (Danakil depression, Ethiopia), approximate scale 1:100.000. CNR-CNRS, Geotechnip.

Barberi, F., Cheminee, J.L., and Varet, J. (1973). Long-lived lava lakes of Erta Ale volcano. Revue de Geographie Physique et de Geologie Dynamique, 15, 347-352.

Barberi, F., Ferrara, G., Santacroce, R., and Varet, J. (1975). Structural evolution of the Afar triple junction. In: Pilger, A., Rosler, A. (Eds.), Afar Depression of Ethiopia. Stuttgart, 1, pp. 39-54.

Barberi, F., Civetta, L., and Varet, J. (1980). Sr isotopic composition of Afar volcanics and its implication for mantle evolution. Earth and Planetary Science Letters, 50, 247-259.

Bendick, R., McClusky, S., Bilham, R., Asfaw, L., and Klemperer, S. (2006). Distributed Nubia-Somalia relative motion and dike intrusion in the Main Ethiopian Rift. Geophysical Journal International, 165, 303-310.

Biggs, J., Amelung, F., Gourmelen, N., Dixon, T. H., and Kim, S.W. (2009). InSAR observations of 2007 Tanzania rifting episode reveal mixed fault and dyke extension in an immature continental rift. Geophysical Journal International, 179(1), 549-558. doi:10.1111/j.1365-246X.2009.04262.x 
Bilham, R., Bendick, R., Larson, K., Mohr, P., Braun, J., Tesfaye, S., and Asfaw, L. (1999). Secular and tidal strain across the Main Ethiopian Rift. Geophysical Research Letters, 26, 2789-2792.

Bjornsson, A., Saemundsson, K., Einarsson, P., Tryggvason, E., and Gronvold, K. (1977). Current rifting episode in North Iceland. Nature, 266, 318-322.

Brandsdóttir, B., Menke, W. H., Einarsson, P., White, R. S., and Staples, R. K. (1997). Faroe-Iceland Ridge Experiment. 2. Crustal structure of the Krafla central volcano. Journal of Geophysical Research, 102(B4), 7867-7886.

Buck, W.R. (2006). The role of magma in the development of the Afro-Arabian Rift System. Geological Society of London, Special Publications, 259, 43-54.

Buck, W.R., Einarsson, P., and Brandsdóttir, B. (2006). Tectonic stress and magma chamber size as controls on dike propagation: constraints from the 1975-1984 Krafla rifting episode. Journal of Geophysical Research, 111(B12), B12, 404. Doi: 10.1029/2005JB003879

Bull, J.M., Minshull, T.A., Mitchell, N.C., Dix, J.K., and Harnardottir, J. (2005). Magmatic and tectonic history of Iceland's western rift zone at Lake Thingvallavatn. Geological Society of America Bulletin, 117, 1451-1465.

Calais, E., d'Oreye, N., Albaric, J., Deschamps, A., Delvaux, D., Déverchère, J., Ebinger, C., Ferdinand, R.W., Kervyn, F., Macheyeki, S.A., Oyen, A., Perrot, J., Saria, E., Smets, B., Stamps, D.S. and Wauthier, C. (2008). Strain accommodation by slow slip and dyking in a youthful continental rift, East Africa. Nature Letters, 456, 783-788. Doi: 10.1038/nature07478.

Cartwright, J.A., and Mansfield, C.S. (1998). Lateral displacement variation and lateral tip geometry of normal faults in the Canyonlands National Park, Utah. Journal of Structural Geology, 20(1), 3-19.

Casey, M., Ebinger, C., Keir, D., Gloaguen, R., and Mohamed, F. (2006). Strain accommodation in transitional rifts: extension by magma intrusion and faulting in Ethiopian rift magmatic segments. In: Yirgu, G., Ebinger, C.J., Maguire, P.K.H. (Eds.), The Afar Volcanic Province within the East African Rift System. Geological Society of London, Special Publications, 259, 143-163.

Cattin, R., Doubre, C., de Chabalier, J.B., King, G., Vigny, C., Avouac, J.P., and Ruegg, J.C. (2005). Numerical modeling of Quaternary deformation and post-rifting displacement in the Asal-Ghoubbet rift (Djibouti, Africa). Earth and Planetary Science Letters, 239, 352-367.

Clifton, A.E., and Kattenhorn, S.A. (2006). Structural architecture of a highly oblique divergent plate boundary segment. Tectonophysics, 419, 27-40.

Corti, G. (2008). Control of rift obliquity on the evolution and segmentation of the main Ethiopian rift. Nature Geoscience, 1, 258-262.

Corti, G. (2009). Continental rift evolution: from rift initiation to incipient break-up in the Main Ethiopian Rift, East Africa. Earth-Science Reviews, 96, 1-53.

Courtillot, V., Achache, J., Landre, F., Bonhommet, N., Montigny, R., and Feraud, G. (1984). Episodic spreading and rift propagation: new palomagnetic and geochronologic data from the Afar nascent passive margin. Journal of Geophysical Research, 89, 3315-3333.

Daly, E., Keir, D., Ebinger, C.J., Stuart, G.W., Bastow, I.D., and Ayele, A. (2008). Crustal tomographic imaging of a transitional continental rift: the Ethiopian rift. Geophysics Journal International, 172, 1033-1048. 
DeMets, C., Gordon, R., and Argus, D. (2010). Geologically current plate motions. Geophysical Journal International, 181, 1-80, Doi: 10.1111/j.1365 -246X .2009 .04491.x

Ebinger, C., 2005. Continental breakup: the East African perspective. Astron. Geophys. 46, 2.16-2.21.

Ebinger, C.J., and Hayward, N.J. (1996). Soft plates and hot spots: views from Afar. Journal of Geophysical Research, 101, 21859-21876.

Ebinger, C. J., and Casey, M. (2001). Continental breakup in magmatic provinces: An Ethiopian example. Geology, 29, 527-530. Doi: 10.1130/0091-7613(2001)029<0527

Ebinger, C.J., Keir, D., Ayele, A., Calais, E., Wright, T.J., Belachew, M., Hammond, J.O.S., Campbell, E., and Buck, W.R. (2008). Capturing magma intrusion and faulting processes during continental rupture: seismicity of the Dabbahu (Afar) rift. Geophysics Journal International, 174, 1138-1152.

Ebinger, C., Ayele, A., Keir, D., Rowland, J. V, Yirgu, G., Wright, T., Hamling, I. (2010). Length and Timescales of Rift Faulting and Magma Intrusion: The Afar Rifting Cycle from 2005 to Present. Annual Review of Planetary Science, 38, 439-466. Doi: 10.1146/annurevearth-040809-152333

Einarsson, P., (1991). Earthquakes and present-day tectonism in Iceland. Tectonophysics, 189, 261-279.

Fernandes, R.M.S., Ambrosius, B.A.C., Noomen, R., Bastos, L., Combrinck, L., Miranda, and J.M., Spakman, W. (2004). Angular velocities of Nubia and Somalia from continuous GPS data: implications on present-day relative kinematics. Earth Planetary Science Letters, 222, 197-208.

Ferril, D.A., Morris, A.P. and McGinnis, R.N. (2012). Extensional fault-propagation folding in mechanically layered rocks: the case against the frictional drag mechanism. Tectonophysics, 576-577, 78-85.

Forslund, T., and Gudmundsson, A. (1992). Structure of Tertiary and Pleistocene normal faults in Iceland. Tectonics, 11, 57-68.

Grandin, R., Socquet, A., Binet, R., Klinger, Y., Jacques, E., de Chabalier, J.B., King, G.C.P., Lasserre, C., Tait, S., Tapponnier, P., Delorme, A., and Pinzuti, P. (2009). September 2005 Manda Hararo-Dabbahu rifting event, Afar (Ethiopia): constraints provided by geodetic data. Journal of Geophysical Research, 114, B08404. Doi: http://dx.doi.org/10.1029/2008JB005843.

Grant, J. V, and Kattenhorn, S. A. (2004). Evolution of vertical faults at an extensional plate boundary, Southwest Iceland. Journal of Structural Geology, 26, 537-557. Doi:10.1016/j.jsg.2003.07.003

Gudmundsson, A. (1980). The Vogar fissure swarm, Reykjanes Peninsula, SW Iceland. Jokull, 30, 43-64.

Gudmundsson, A. (1983). Stress estimates from the length/width ratios of fractures. Journal of Structural Geology, 5, 623-626.

Gudmundsson, A. (1984). Tectonic aspect of dykes in Northern western Iceland. Jokull, 34, 81-96.

Gudmundsson, A. (1987). Tectonics of the Thingvellir fissure swarm, SW Iceland. Journal of Structural Geology, 9(1), 61-69.

Gudmundsson, A. (1987b). Geometry, formation and development of tectonic fractures on the Reykjanes Peninsula, Southwest Iceland. Tectonophysics, 139, 295-308. 
Gudmundsson, A. (1990). Dyke emplacement at divergent plate boundaries. Mafic dykes and emplacement mechanisms, 47-62.

Gudmundsson, A. (1992). Formation and growth of normal faults at the divergent plate boundary in Iceland. Terra Nova, 4, 464-471.

Gudmundsson, A. (1995a). Infrastructure and mechanics of volcanic systems in Iceland. Journal of Volcanology and Geothermal Research, 64, 1-22.

Gudmundsson, A. (1995b). Ocean-ridge discontinuities in Iceland. Journal of Geological Society of London, 152, 1011-1015.

Gudmundsson, A. (2000). Dynamics of volcanic systems in Iceland: example of tectonism and volcanism at juxtaposed hot spot and Mid-Ocean Ridge system. Annual Review of Earth and Planetary Science, 28, 107-140.

Gudmundsson, A. (2003). Surface stresses associated with arrested dykes in rift zones. Bulletin Volcanology, 65, 606-619.

Gudmundsson, A. (2005). Effect of mechanical layering on the development of normal faults and dykes in Iceland. Geodinamica Acta, 18(1), 11-30.

Gudmundsson, A. (2007). Infrastructure and evolution of ocean-ridge discontinuities in Iceland. J.'Geodyn., 43, 6-29.

Gudmundsson, A. and Backstrom, K. (1991). Structure and development of the Sveinagja graben, Northeast Iceland. Tectonophysics, 200, 111-125.

Gudmundsson, A. and Brynjolfsson, S., (1993). Overlapping rift-zone segments and the evolution of the South Iceland Seismic Zone. Geophysical Research Letters, 20, 19031906.

Hammer, C.U. (1984). Traces of Icelandic eruptions in the Greenland ice sheet. Jokull, 34, 51-65.

Hardy, S. (2013). Propagation of blind normal faults to the surface in basaltic sequences: Insights from 2D discrete element modelling. Marine and Petroleum Geology, 48, 149-159.

Helgason, J., and Zentilli, M. (1985). Field characteristics of laterally emplaced dikes: anatomy of an exhumed Miocene dike swarm in Reydarfjordur, eastern Iceland. Tectonophysics, 115, 247-274.

Hofton, M.A., and Fougler, G.R. (1996). Postrifting anelastic deformation around the spreading plate boundary, North Iceland. 1. Modeling of the 1987-1992 deformation field using viscoelastic Earth structure. Journal of Geophysical Research, 101(B11), 25,40325,421 .

Hollingsworth, J., Leprince, S., Ayoub, F., and Avouac J.P. (2012). Deformation during the 1975-1984 Krafla rifting crisis, NE Iceland, measured from historical optical imagery. Journal of Geophysical Research, 117(B11407), 1-24. Doi: 10.1029/2012JB009140

Jacques, E., King, G.C.P., Tapponnier, P., Ruegg, J.C., and Manighetti, I. (1996). Seismic activity triggered by stress changes after the 1978 events in the Asal Rift, Djibouti. Geophysical Research Letters, 23, 2481-2484.

Jestin, F., Huchon, P., and Gaulier, J.M. (1994). The Somalia plate and the East African Rift System: present-day kinematics. Geophysical Journal International, 116, 637-654.

Jonsson, S., Einarsson, P., and Sigmundsson, F. (1997). Extension across a divergent plate boundary, the Eastern Volcanic Rift Zone, South Iceland, 1967-1994, observed with GPS and electronic distance measurements. Journal of Geophysical Research, 102(B6), 11,913-11,929. 
Keiding, M., Arnadottir, T., Sturkell, E., Geirsson, H., and Lund, B. (2008). Strain accumulation along an oblique plate boundary: Reykjanes Peninsula, Southwest Iceland. Geophysics Journal International, 172, 861-872.

Keir, D., Hamling, I. J., Ayele, a., Calais, E., Ebinger, C., Wright, T. J., and Bennati, L. (2009). Evidence for focused magmatic accretion at segment centers from lateral dike injections captured beneath the Red Sea rift in Afar. Geology, 37(1), 59-62. Doi:10.1130/G25147A.1

Kendall, J.M., Stuart, G.W., Ebinger, C.J., Bastow, I.D., and Keir, D. (2005). Magmaassisted rifting in Ethiopia. Nature, 433, 146-148.

Keranen, K., Klemperer, S.L., Gloaguen, R., and Eagle Working Group, (2004). Threedimensional seismic imaging of a protoridge axis in the Main Ethiopian Rift. Geology, 32, 949-952.

Keranen, K., and Klemperer, S.L. (2008). Discontinuous and diachronous evolution of the Main Ethiopian Rift: implications for development of continental rifts. Earth and Planetary Science Letters, 265, 96-111.

Kogan, L., Fisseha, S., Bendick, R., Reilinger, R., McClusky, S., King, R., and Solomon, T. (2012). Lithospheric strength and strain localization in continental extension from observations of the East African Rift. Journal of Geophysical Research, 117, B03402.http://dx.doi.org/10. 1029/2011JB008516

LaFemina, P.C., Dixon, T.H., Malservisi, R., Arnadottir, T., Strukell, E., Sigmundsson, F., and Einarsson, P. (2005). Geodetic GPS measurements in South Iceland: strain accumulation and partitioning in a propagating rift. Journal of Geophysical Research, 110, B11405. Doi: http://dx.doi.org/ 10.1029/ 2005JB003675.

Lahitte, P., Gillot, P.Y., Kidane, T., Courtillot, V., and Abebe, B. (2003a). New age constraints on the timing of volcanism in Central Afar, in the presence of propagating rifts. Journal of Geophysical Research, 108, 2123. Doi: http://dx.doi.org/10.1029/2001 JB001689.

Lahitte, P., Gillot, P.Y., and Courtillot, V. (2003b).Silicic central volcanoes as precursors to rift propagation: the Afar case. Earth and Planetary Science Letters, 207, 103-116.

Le Pichon, X., and Franchteau, J. (1978). A plate tectonic analysis of the Red Sea-Gulf of Aden area. Tectonophysics, 46, $369-406$.

Mastin, L.G., and Pollard, D.D. (1988). Surface deformation and shallow dike intrusion processes at Inyo Craters, Long Valley, California. Journal of Geophysical Research, 93(B11), 13,221-13,235.

Manighetti, I., Tapponnier, P., Gillot, P.Y., Jacques, E., Courtillot, V., Armijo, R., Ruegg, J.C., and King, G. (1998). Propagation of rifting along the Arabia-Somalia plate boundary. into Afar. Journal of Geophysical Research, 103, 4947-4974.

Martel, S.J., and Langley J.S. (2006). Propagation of normal faults to the surface in basalt, Koae fault system, Hawaii. Journal of Structural Geology, 28, 2123-2143.

McKenzie, D.P., Davies, D., and Molnar, P. (1970). Plate tectonics of the Red Sea and East Africa. Nature, 226, 243 - 248.

McClusky, S., Reilinger, R., Ogubazghi, G., Amleson, A., Healeb, B., Vernant, P., Sholan, J., Fisseha, S., Asfaw, L., Bendick, R., and Kogan, L. (2010). Kinematics of the Southern Red Sea-Afar triple junction and implications for plate dynamics. Geophysical Research Letters, 37, L05301. Doi: http://dx.doi.org/10.1029/2009GL0411-27. 
Mickus, K., Tadesse, K., Keller, G.R., and Oluma, B. (2007). Gravity analysis of the main Ethiopian rift. J. Afr. Earth Sci., 48, 59-69.

Mohr, P. (1967). Major volcano-tectonic lineament in the Ethiopian Rift System. Nature, 213, 664-665.

Mohr, P. (1987). Patterns of faulting in the Ethiopian rift Valley. Tectonophysics, 143, 169-179.

Nobile, A., Pagli, C., Keir, D., Wright, T. J., Ayele, A., Ruch, J., and Acocella, V. (2012). Dike-fault interaction during the 2004 Dallol intrusion at the Northern edge of the Erta Ale Ridge (Afar, Ethiopia). Geophysical Research Letters, 39, 1-6. Doi: 10.1029/2012GL053152

Norini, G., Acocella, V., Gudmundsson, A., Lagmay, M., and Paguican, E. (2009). Oblique spreading, extensional fractures, and fault growth on the rift zone of SW Iceland. Egu abstract, Vienna 2009.

Opheim, J. A., and Gudmundsson, A. (1989). Formation and geometry of fractures, and related volcanism, of the Krafla fissure swarm, Northeast Iceland. Geological Society of Aamerica Bulletin, 101(12), 1608-1622.

Oppenheimer, C., and Francis, P. (1998). Implications of longeval lava lakes for geomorphological and plutonic processes at Erta Ale volcano, Afar. Journal of Volcanology and Geothermal Research, 80, 101-111.

Pallister, J.S., McCausland, W.A., Jonsson, S., Lu, Z., Zahran, H.M., El Hadidy, S., Abrukbah, A., Stewart, I.C.F., Lundgren, P.R., White, R.A., and Moufti, M.R.H. (2010). Broad accommodation of rift-related extension recorder by dyke intrusion in Saudi Arabia. Nature Geoscience, 3(10), 708-712. Doi: 10.1038/ngeo966

Paquet, F., Dauteuil, O., Hallot, E., and Moreau, F. (2007). Tectonics and magma dynamics coupling in a dyke swarm of Iceland. Journal of Structural Geology, 29(9), 14771493. Doi:10.1016/j.jsg.2007.06.001

Perlt, J., Heinert, M., and Niemeier, W. (2008). The continental margin in Iceland - A snapshot derived from combined GPS networks. Tectonophysics, 447(1-4), 155-166. Doi:10.1016/j.tecto.2006.09.020

Pinzuti, P., Mignan, A., King, and G.C.P. (2010). Surface morphology of active normal faults in hard rock: implications for the mechanics of the Asal Rift, Djibouti. Earth and Planetary Science Letters, 299,169-179.

Podolsky, M.W. and Roberts, G.P. (2008). Growth of the volcano-flank Koa'e fault system, Hawaii. Journal of Structural Geology, 30(10), 1254-1263.

Rowland, J.V., Baker, E., Ebinger, C.J., Keir, D., Kidane, T., Biggs, J., Wright, T.J. (2007). Fault growth at a nascent slow-spreading ridge: 2005 Dabbahu rifting episode, Afar. Geophysical Journal International, 171(3), 1226-1246. Doi: 10.1111/j.1365246X.2007.03584.X.

Rubin, A.M. (1992). Dike-induced faulting and graben subsidence in volcanic rift zones. Journal of Geophysical Research, 97(B2), 1839-1858.

Rubin, A.M., and Pollard, D.D. (1988). Dike-induced faulting in rift zones of Iceland and Afar. Geology, 16, 413-417.

Ruegg, J.C., Lépine, J.C., and Tarantola, A. (1979). Geodetic measurements of rifting associated with a seismo-volcanic crisis in Afar. Geophysical Research Letters, 6(11), 817820. 
Saemundsson, K. (1992). Geology of the Thingvallavatn area. Oikos, 64, 40-68.

Siebert, L., Simkin, T., and Kimberly, P. (2010). Volcanoes of the World, 3rd Ed. University of California Press, Berkeley, 568 pp.

Sigmundsson, F. (2006a). Iceland geodynamics. Crustal deformation and divergent plate tectonics. Ed. Springer and Praxis Publishing, 247 pp.

Sigmundsson, F. (2006b). Magma does the splits. Nature, 442, 251-252.

Sigmundsson, F., Hooper, A., Hreinsdottir, S., Vogfjord, K.S., Ofeigsson, D.G., Heimisson, E.L., Dumont, S., Parks, M., Spaans, K., Gudmundsson, G.B., Drouin, V., Arnadottir, T., Jonsdottir, K., Gudmundsson, M.T., Hognadottir, T., Fridriksdottir, H.M., Hensch, M., Einarsson, P., Magnusson, E., Samsonov, S., Brandsdottir, B., White, R.S., Agustsdottir, T., Greenfield, T., Green, R.G.,Hjartardottir, A., Pedersen, R., Bennett, R., Geirsson, H., La Femina, P.C., Bjornsson, H., Palsson, F., Sturkell, E., Bean, C.J. , Mollhoff, M., Braiden, A.K., and Eibl, E. (2015). Segmented lateral dyke growth in a rifting event at Barðarbunga volcanic system, Iceland. Nature, 517, 191-195. Doi: doi:10.1038/nature14111.

Sigurdsson, O. (1980). Surface deformation of the Krafla fissure swarm in two rifting events. Journal of Geophysical Researches, 47, 154-159.

Sigurdsson, H., and Sparks, S. (1978). Rifting episode in North Iceland in 1874-1875 and the eruptions of Askja and Sveinagja. Bulletin of Volcanology, 41, 149-167.

Sonnette, L., Angelier, J., Villemin, and T., Bergerat, F. (2010). Faulting and fissuring in active oceanic rift: surface expression, distribution and tectonic-volcanic interaction in the Thingvellir fissure swarm, Iceland. Journal of Structural Geology, 32, 407-422.

Tapponnier, P., Armijo, R., Manighetti, I., and Courtillot, V. (1990). Bookshelf faulting and horizontal block rotations between overlapping rifts in Southern Afar. Geophysical Research Letters, 17, 1-4.

Tarantola, A., Ruegg, J.C. and Lépine, J.P. (1980). Geodetic evidence for rifting in Afar, 2. Vertical displacement. Earth and Planetary Science Letters, 48, 363-370.

Tentler, T. (2005). Propagation of brittle failure triggered by magma in Iceland. Tectonophysics, 406(1-2), 17-38. Doi:10.1016/j.tecto.2005.05.016

Tentler, T., and Mazzoli, S. (2005). Architecture of normal faults in the rift zone of central North Iceland. Journal of Structural Geology, 27, 1721-1739. Doi: 10.1016/j.jsg.2005.05.018

Thorarinsson, S. (1959). Some geological problems involved in the hydroelectric development of the Jokulsa a Fjollum, Iceland. Report to the State Electricity Authority, Reykjavik.

Thordarson, T., Miller, D.J., Larsen, G., Self, S., and Sigurdsson, H., (2001). New estimates of sulfur degassing and atmospheric mass-loading by the 934 AD Eldjá eruption, Iceland. Journal of Volcanology and Geothermal Research, 108, 33-54. Doi: 10.1016/S0377-0273(00)00277-8.

Thordarson, T., and Self, S. (1993). The Laki (Skaftlir Fires) and Grimsvotn eruptions in 1783-1785. Bulletin of Volcanology, 55, 233-263.

Trippanera, D., Acocella, V., and Ruch, J. (2014). Dike-induced contraction along oceanic and continental divergent plate boundaries. Geophysical Research Letters, 40, 1-7. Doi: 10.1002/2014GL061570 
Trippanera, D., Acocella, V., Ruch, J. and Rivalta, E. (2015). How diking affects the longer-term structure and evolution of divergent plate boundaries. Geophysical Research Abstracts, 17, EGU2015-5672, Egu General Assembly 2015, Wien.

Tryggvason, E. (1980). Subsidence events in the Krafla area, North Iceland, 1975 1979, Journal of Geophysics, 47, $141-153$

Tryggvason, E. (1984). Widening of the Krafla fissure swarm during the 1975-1981 volcano-tectonic episode. Bulletin of Volcanology, 47, 47-69.s

Tryggvason, E. (1994). Surface deformation at the Krafla volcano, North Iceland, 19821992. Bulletin of Volcanology, 56, 98-107.

Urbani, S., Trippanera, D., Porreca, M., Kissel, C. and Acocella, V. (2015). Anatomy of an extinct magmatic system along a divergent plate boundary: Alftafjordur, Iceland. Geophysical Research Letters, 42, 15. Doi: 10.1002/2015GL065087.

Vigny, C., de Chabalier, J.B., Ruegg, J.C., Huchon, P., Feigl, K.L., Cattin, R., Asfaw, L., and Kanbari, K. (2007). Twenty-five years of geodetic measurements along the TadjouraAsal rift system, Djibuti, East Africa. Journal of Geophysical Research, 112, B06410. Doi: http://dx.doi.org/10.1029/2004JB003230.

Villemin, T., and Bergerat, F. (2013). From surface fault traces to a fault growth model: the Vogar Fissure Swarm of the Reykjanes Peninsula, Southwest Iceland. Journal of Structural Geology, 51, 38-51. Doi: http://dx.doi.org/10.1016/j.jsg.2013.03.010.

Walker, G.P.L. (1958). Geology of the Reydarfjordur Area, Eastern Iceland. Quarterly Journal of the Geological Society, 114(1-4), 367-391. Doi:10.1144/gsjgs.114.1.0367

Walker, G.P.L. (1960). Zeolite zones and dike distribution in relation to the structure of the basalts of Eastern Iceland. Journal of the Geological Society of London, 68, 515-527.

Walpersdorf, A., Vigny, C., Ruegg, J.C., Huchon, P., Asfaw, L.M., and Al Kirbash, S. (1999). 5 years of GPS observations of the Afar triple junction area. Journal of Geodynamics, 28, 225-236.

Williams, F.M., Williams, M.A.J., and Aumento, F. (2004). Tensional fissures and crustal extension rates in the Northern part of the Main Ethiopian Rift. J. Afr. Earth Sci. 38, 183197.

Woldegabriel, G., Aronson, J.L., and Walter, R.C. (1990). Geology, geochronology and rift basin development in the central sector of the Main Ethiopian Rift. Geological Society of America Bulletin, 102, 439-458.

Wright, T. J., Ebinger, C., Biggs, J., Ayele, A., Yirgu, G., Keir, D., and Stork, A. (2006). Magma-maintained rift segmentation at continental rupture in the 2005 Afar dyking episode. Nature, 1-5. Doi: 10.1038/nature04978

Zielinsky, G.A., Germani, M.S., Larsen, G., Baillie, M.G.L., Whitlow, S., Twicker, M.S., and Taylor, K. (1995). Evidence of the Eldgjá (Iceland) eruption in the GISP2 Greenland ice core: relationship to eruption processes and climatic conditions in the tenth century. The Holocene, 5, 129-140.

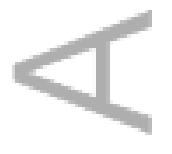

\section{Captions}


Table 1: Summary of the mean structural features of the investigated fissure swarms, including the number of the observed fault tips (FPF = fold propagation folding type; OPF = open fracture type), the mean throw, opening and tilt of the hanging wall $(\mathrm{Hw})$ of the normal faults, as well the maximum values of throw, opening and Hw tilt observed on a single fault. $\mathrm{EF}=$ Eruptive fissures within the graben; $\mathrm{C}=$ Contraction at the base of the tilted hanging wall.

Fig.1: (a) Map of Iceland (location in the inset) with the magmatic systems. WVZ = Western Volcanic Zone; EVZ = Eastern Volcanic Zone; NVZ = North Volcanic Zone; RLVZ = Reykjanes-Langjokull Volcanic Zone; RR = Reykjanes Ridge; SISZ = South Iceland Seismic Zone; TFZ = Tjörnes Fracture Zone; KR = Kolbeinsey Ridge; MAR = Mid Atlantic Ridge (green line in the inset). (b) Map of the Afar region and the Main Ethiopian Rift (MER; location in the insets) with the magmatic systems [after Ebinger et al., 2008]. The inset C shows a detail of the Central MER (C MER) in which the Wonji Fault Belt (WFB) and Fantale magmatic system (F) are located. S MER = Southern MER; N MER = Northern MER; $\mathrm{D}=$ Dallol; $\mathrm{E}=$ Erta Ale volcano; $\mathrm{Da}=$ Dabbahu rift; $\mathrm{M}=$ Manda Hararo rift; $\mathrm{A}=$ Asal rift; EARS = East African Rift System (green line in the inset). Red squares show the studied areas.

Fig. 2: Scheme of open normal fault with (a) tilted hanging wall and (b) sub-horizontal hanging wall, with definitions. Structure of the lateral tip of the normal faults observed in the field, showing (c) both a flat footwall and hanging wall separated by extension fractures departing (OPF type) or (d) a flat footwall and tilted hanging wall forming a monocline (fault propagation fold type, FPF) [Cartwright and Mansfield, 1998]. Fw = Footwall; Hw = Hanging wall.

Fig. 3: $(a, b)$ Structural map of the Lakagigar immature fissure swarm, Iceland, from South (1) to North (3); scale bar of a) is the same as b). The left inset shows the Eastern Volcanic Zone (EVZ) with the location of Lakagigar (L) and Eldgjá (E) fissures (yellow dots). The Katla (K) and Grimsvotn (G) magmatic systems are highlighted in red. SW: SW Eldgjá 
fissure; C: Central Eldgjá fissure; NE: NE Eldgjá fissure. (c) View of the central fissure southwards from the Laki hill (location in a; white arrow indicates the viewpoint); the central part of the faults bounding the fissure (black lines) and the tilt of both footwall and hanging wall (white lines) are highlighted; (d) rose diagram of the eruptive fissures and normal faults strikes; (e, f) frequency histogram of the fault throw and opening; $(g)$ profiles along the lines A-A' (above) and B-B' (below), locations in a and b respectively.

Fig. 4: $(a, b, c)$ Structural maps of the investigated portions of the Eldgjá immature fissure swarm, Iceland. The base maps are extracted from Google Earth. The location of the fissures is shown in the inset of Fig. 3a. (d) Rose diagram of the faults strikes; (e, f, g) frequency histogram of the fault throw, opening and amount of tilt of the hanging wall. (h) View of the graben on the SW segment (location in a). Here the border faults are exposed on a cliff, highlighting a dip of $\sim 80^{\circ}$. (i) Section A-A' (at the NW segment; location in c): open border fault with inward tilted hanging wall. A scheme of the fault geometry is given in the inset.

Fig. 5: (a) Structural map of the Sveinagja immature fissure swarm, Iceland [from Gudmundsson and Backstrom, 1991], in which the studied area is highlighted (red rectangle). The inset shows the North Volcanic Zone (NVZ) with the location of the Sveinagja graben (yellow dot) within the Askja magmatic system (A); (b) Rose diagram of the normalfaults strike; (c) frequency histogram of the normal faults throw; (d) example of the central portion of an open normal fault with tilted hanging wall along the eastern border of the graben (location in a).

Fig. 6 (a) Structural map of the Sveinar immature fissure swarm, Iceland [from Tentler and Mazzoli, 2005]; the studied area is shown by the red rectangle); The inset shows the North Volcanic Zone (NVZ) with the location of the Sveinar graben (yellow dot) within the Fremri-Namur magmatic system (F); (b) detailed field map of the studied area with relative profiles perpendicular to the fault strike, highlighting the variations of the fault structure in a few hundreds of meters; (c, d) photos of the central part of the border faults, showing an 
open structure with flat footwall and nearly subvertical hanging wall (location in b). In (d) the base of the tilted hanging wall is almost overturned; (e) detailed scheme of d), highlighting the very steep base of tilted hanging wall.

Fig. 7: a) Schematic structure of the Erta Ale Range (Northern Afar, Ethiopia, location in Fig. 1b). b) Overview of the Erta Ale volcano, with the summit caldera and the two fissure swarms, or rift zones, whose structures is partly shown in detail in c) and d). e) Detail of the OPF tip structure of a normal fault along the North Rift, showing an OPF type.

Fig. 8: (a) Structural map of the Krafla mature fissure swarm, Iceland [after Opheim and Gudmundsson, 1989]; (b) rose diagram of the normal faults and extension fractures strikes; (c, d) frequency histogram of the faults throw and amount of hanging wall tilt; (e) frequency histogram of the normal faults (black) and extension fractures (gray) opening. (f) Minor inner graben with several extension fractures located in the central portion of the Krafla magmatic system (within the Krafla caldera); (g) example of OPF lateral termination at Krafla (location in a); the fault increases its displacement to the back of the photographer; ( $h$ ) high throw $(>20 \mathrm{~m})$ fault with pervasive fracturing of the hanging wall, close to Mofell area in centralnorthern Krafla. (i) Grjotagja open normal fault showing a tilted hanging wall and contraction at its base (details in $\mathrm{m}$ ); the inset in $\mathrm{f}, \mathrm{g}, \mathrm{h}$ and I schematically show the geometrical structure of the fault in the relative photo.

Fig. 9: a) Detailed field map of the lateral termination of a $N 40^{\circ}$ oriented open normal fault having a tilted hanging wall and contraction at its base (section A-A') on the southern fissure swarm of Krafla, Iceland (location in Fig. 8a). The tip of the fault, enlarged in b, grades in a series of open fractures in a flat area (also shown in section B-B'), indicating an OPF structure. In a the numbers close to the faults indicate the amount of throw, in meters; in $b$ the numbers close the fractures indicate the amount of opening of the extension fractures, in meters. 
Fig. 10: (a) Map of SW Iceland and the related magmatic systems [Villemin and Bergerat, 2013]; the studied systems are outlined in red; (b) structural map of the Vogar mature fissure swarm; light grey: Upper Pleistocene hyaloclastites and lavas; white: Postglacial lavas, older than AD 871; dark grey: Postglacial lavas, younger than AD 871 [Villemin and Bergerat, 2013]. (c) OPF and (d) FPF lateral fault termination at Vogar (location in a); in both cases the fault increases its displacement to the back of the photographer; (e) open normal fault with flat footwall, tilted hanging wall and contraction at the hanging wall base (white arrows); (f) scheme of the fault in Fig. e.

Fig. 11: (a) Structural map of the Thingvellir mature fissure swarm, Iceland (location in Fig. 10a) [after Bull et al., 2005]. (b) Typical open border fault with tilted hanging wall close to Thingvallavatn Lake (location in a); (c) schematic structure of the fault in b; (d) lateral fault termination of FPF type, with diffuse open fractures over a monocline, at the southernmost portion of Almannagjà Fault (location in a); (e) detailed map of the lateral termination of Almannagjà Fault. The fault termination is characterized by a series of open fractures within a broad monocline tilted up to $\sim 10^{\circ}$, indicating an overall FPF structure.

Fig. 12: a) Structure of the axial portion of the Southern termination of the Manda Hararo mature fissure swarm, central Afar, Ethiopia (location in Fig. 1b). b) Detail of the structure of a particularly well-exposed portion of the swarm, showing the opening (values in meters) of the fractures and the vertical displacement (values in meters, in bold) of the normal faults. c) and d) Details of the structure of three OPF tips of two normal faults (location in a).

Fig. 13: (a) Structural map of the Fantale magmatic system, MER; (b) structural map of the southern fissure swarm (location in a). The rose diagram indicates the fault strike. The types of lateral termination of the faults are indicated by yellow (open fracture type) and green (fold propagation folding type) points. Red points indicate the vents. (c) Frequency histogram showing the amount of hanging wall tilt; (d) open normal fault with a flat footwall $(\mathrm{Fw})$, a tilted hanging wall ( $\mathrm{Hw}$ ) and contraction at its base (white arrows); (e) open normal fault with highly tilted hanging wall (location in b); (f) example of OPF tip; the fault increases 
its displacement to the back of the photographer (location in b); (g) example of FPF tip (location in b).

Fig. 14: Scheme showing the most common faulting structures (in section view) found along immature and mature fissure swarms. Below each case the location(s) where a structure type is most common is reported.

Fig. 15: Normal faults measured in the field in the studied areas. Comparison between the: (a) dilation and vertical displacement; (b) vertical displacement and tilt of the hanging wall, (c) dilation and tilt of the hanging wall.

Fig. 16: (a-c) Block diagrams showing the formation of open fractures type (OPF) of fault termination leading to the downward propagation of normal faults during dike emplacement; (d-f) Block diagrams showing the formation of monocline type (FPF) of fault termination due to a fault propagation folding mechanism induced by upward propagating pre-existing faults buried by lavas and reactivated by dikes. Red arrows indicate the direction of fault propagation, black arrows indicate subsidence or uplift.

Fig. 17: (a) Map of the NNE trending Alftafjordur magmatic system in E Iceland [after Paquet et al., 2007], including the position of the sections; (b) Dike frequency in the sections across the Alftafjordur magmatic system, with respect to the distance from the dominant volcano. The letters above each triangle refer to the sections in a. (c) Values of dike frequency and distance from the dominant volcano and relative references.

Fig. 18: Percentage of dikes with altitude above sea level (a.s.I.) at Alftafjordur [Walker, 1960] and Reydarfjordur [Walker, 1958] in eastern and NW Iceland [Gudmundsson, 1984].

Fig. 19: Amount of slip (numbers above the circles) on faults formed or reactivated during dike intrusion as a function of the dike thickness and its depth. The dike depth (D) is inferred from the graben width $(\mathrm{W})$ formed above the dike and assuming a fault dip of $70^{\circ} . \mathrm{D}=\mathrm{W} / 2$ 
$\tan 70^{\circ}$. References: Acocella and Neri, 2003 (Etna); Rowland, 2007 (Dabbahu); Ruegg et al., 1979 (Asal); Pallister et al., 2010 (Harrat); Rubin, 1992 (Namafjall, Krafla); Jonsson et al., 1997 (Lakagigar).

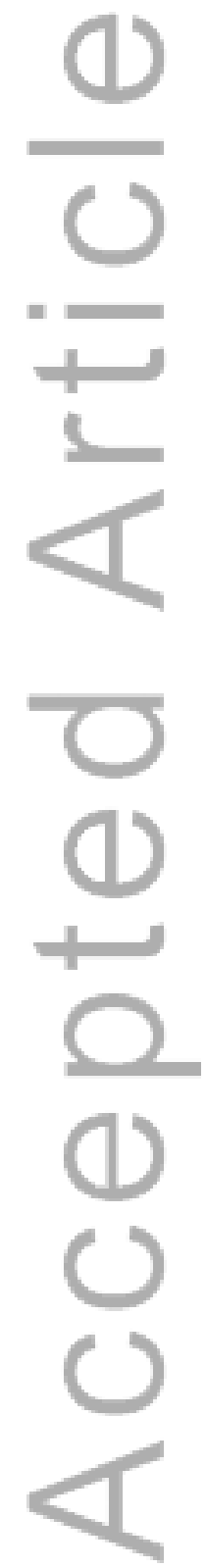




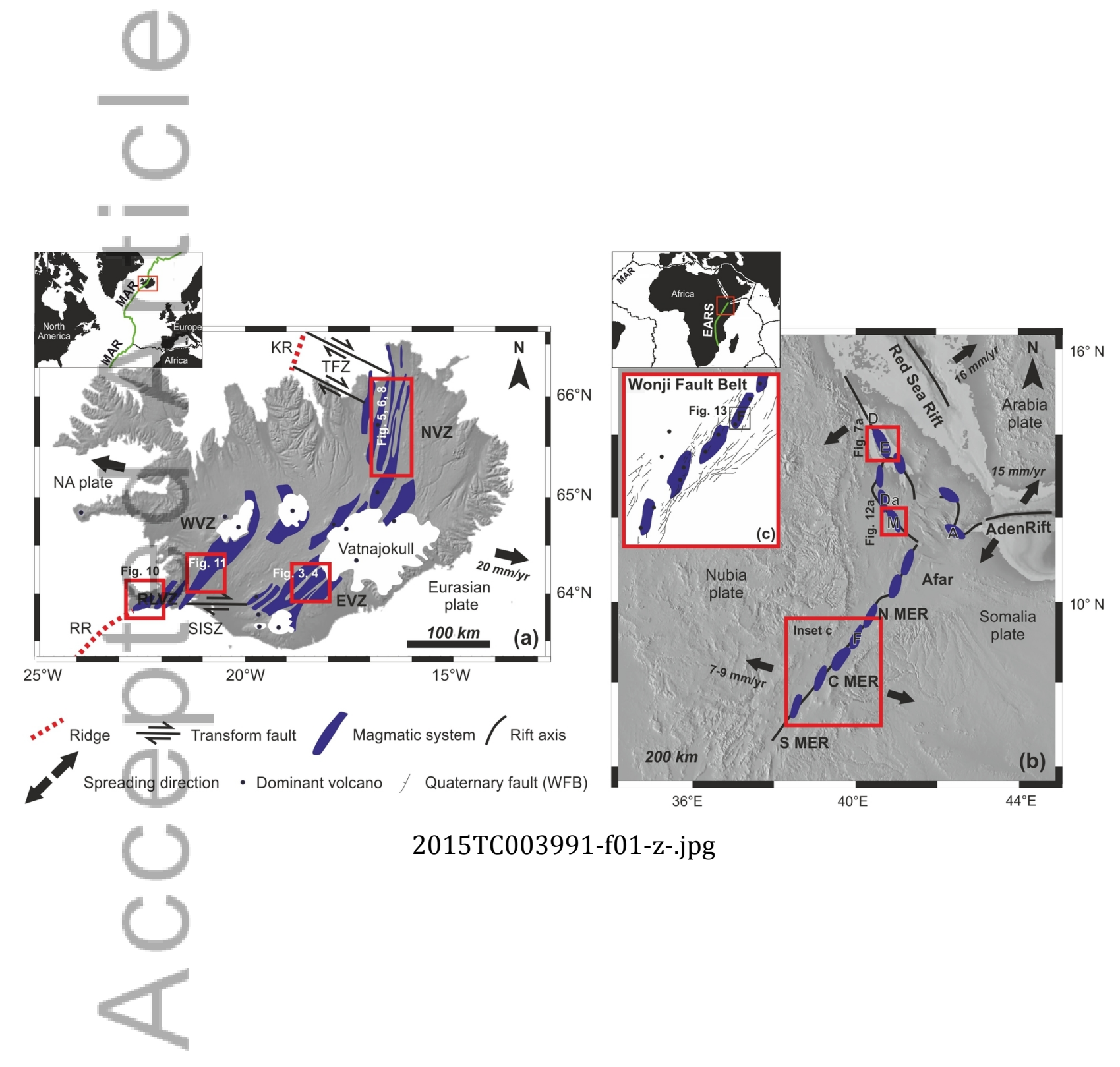

(C)2015 American Geophysical Union. All rights reserved. 


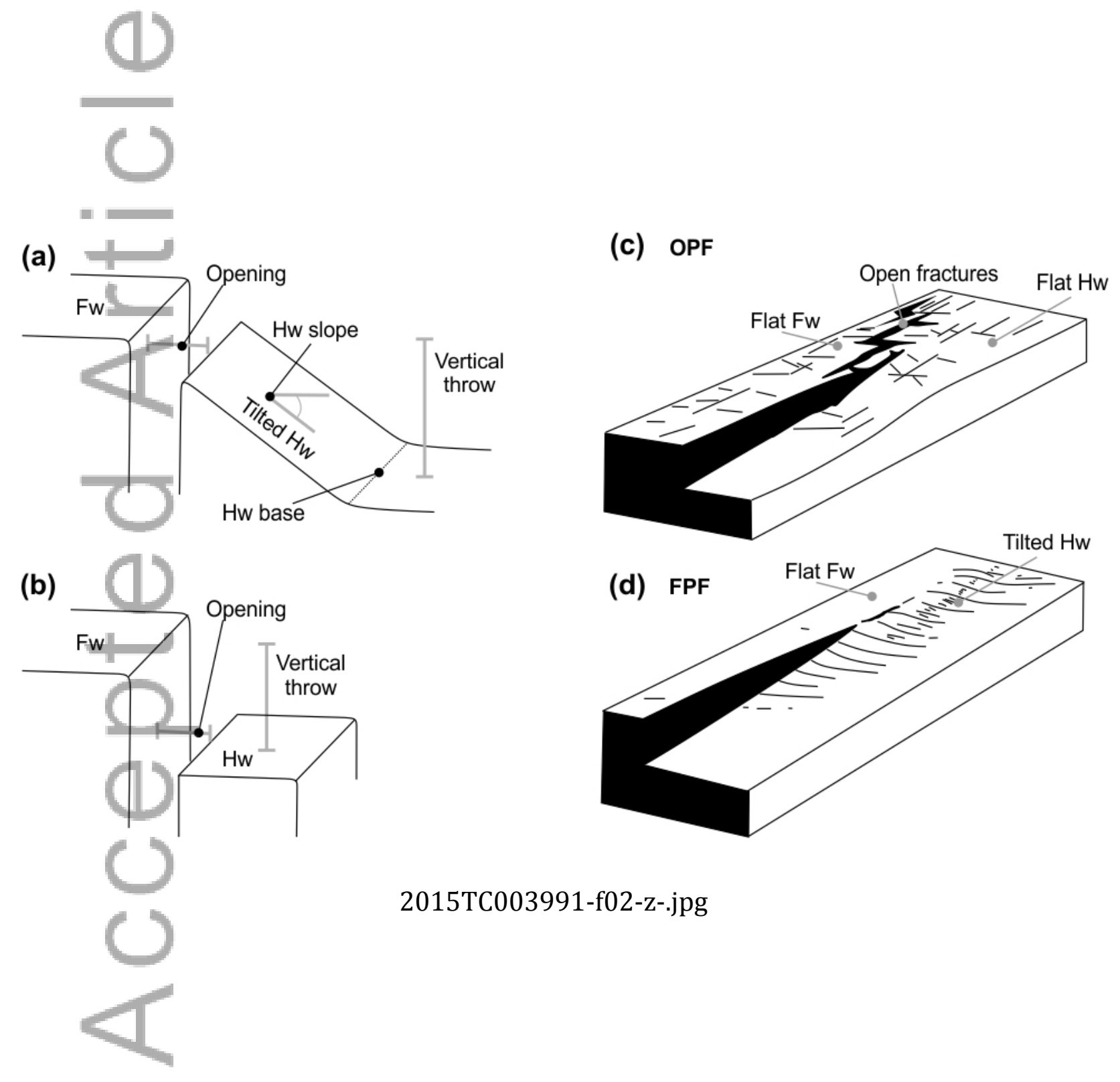



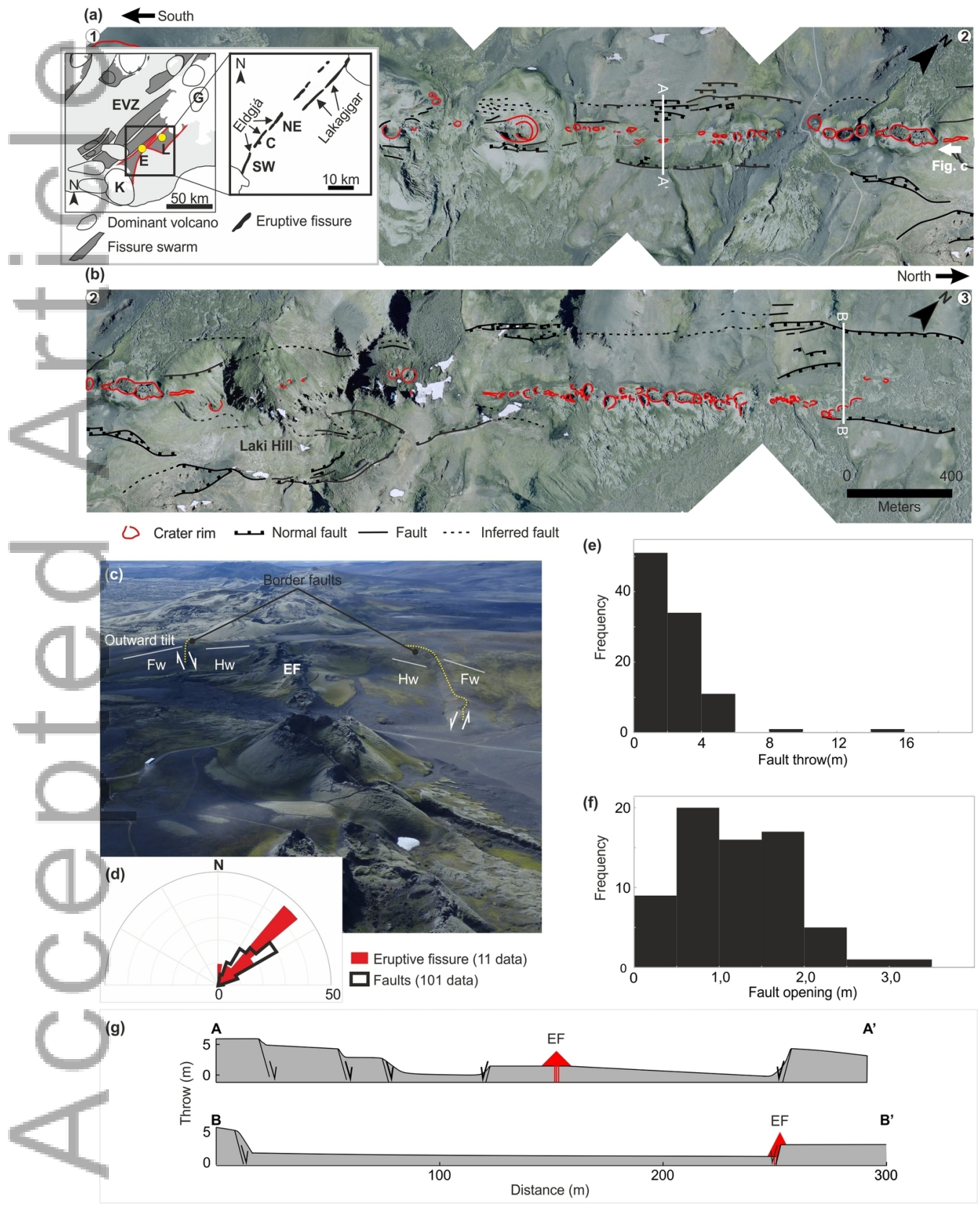

2015TC003991-f03-z-.jpg 

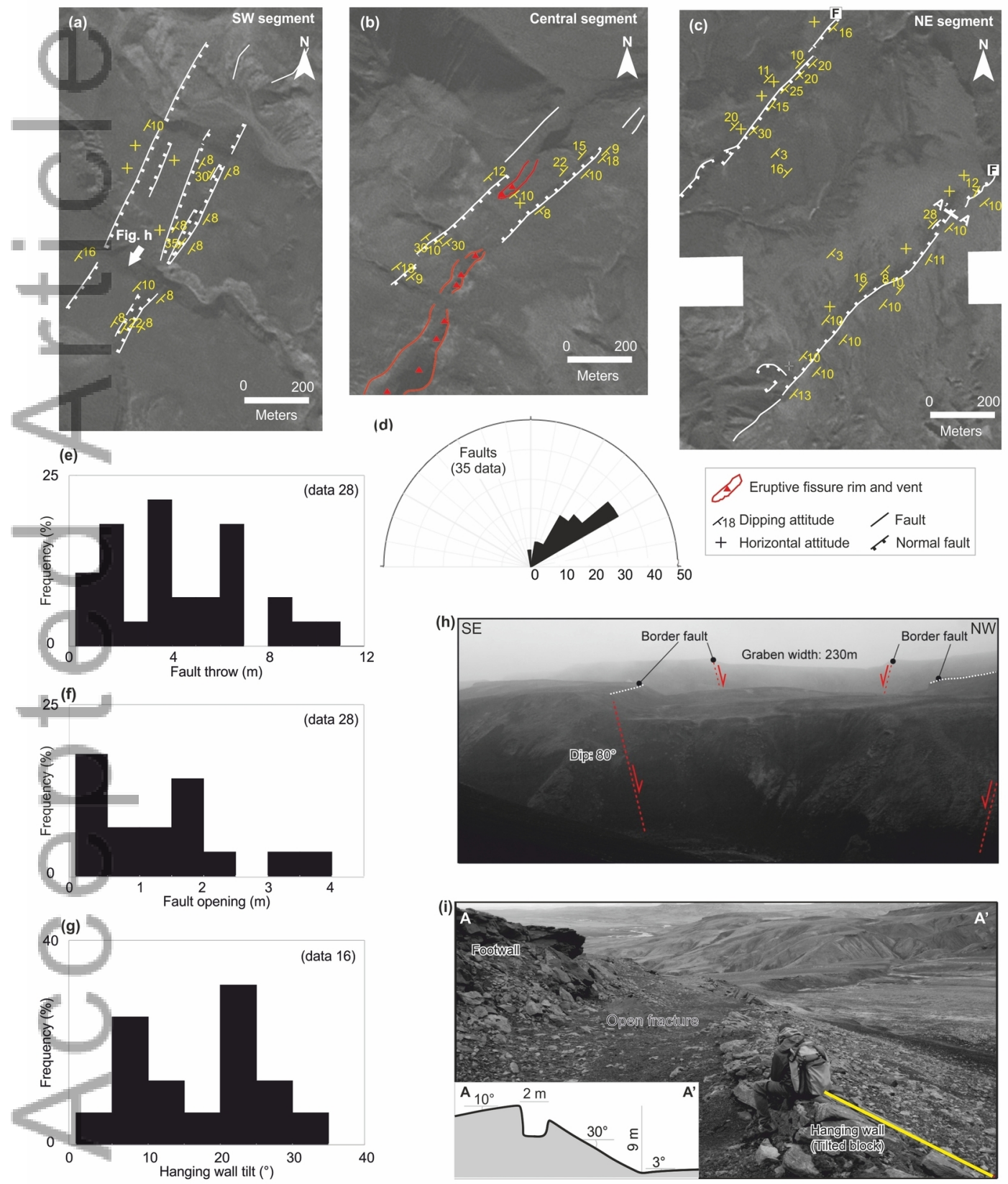

2015TC003991-f04-z-.jpg 

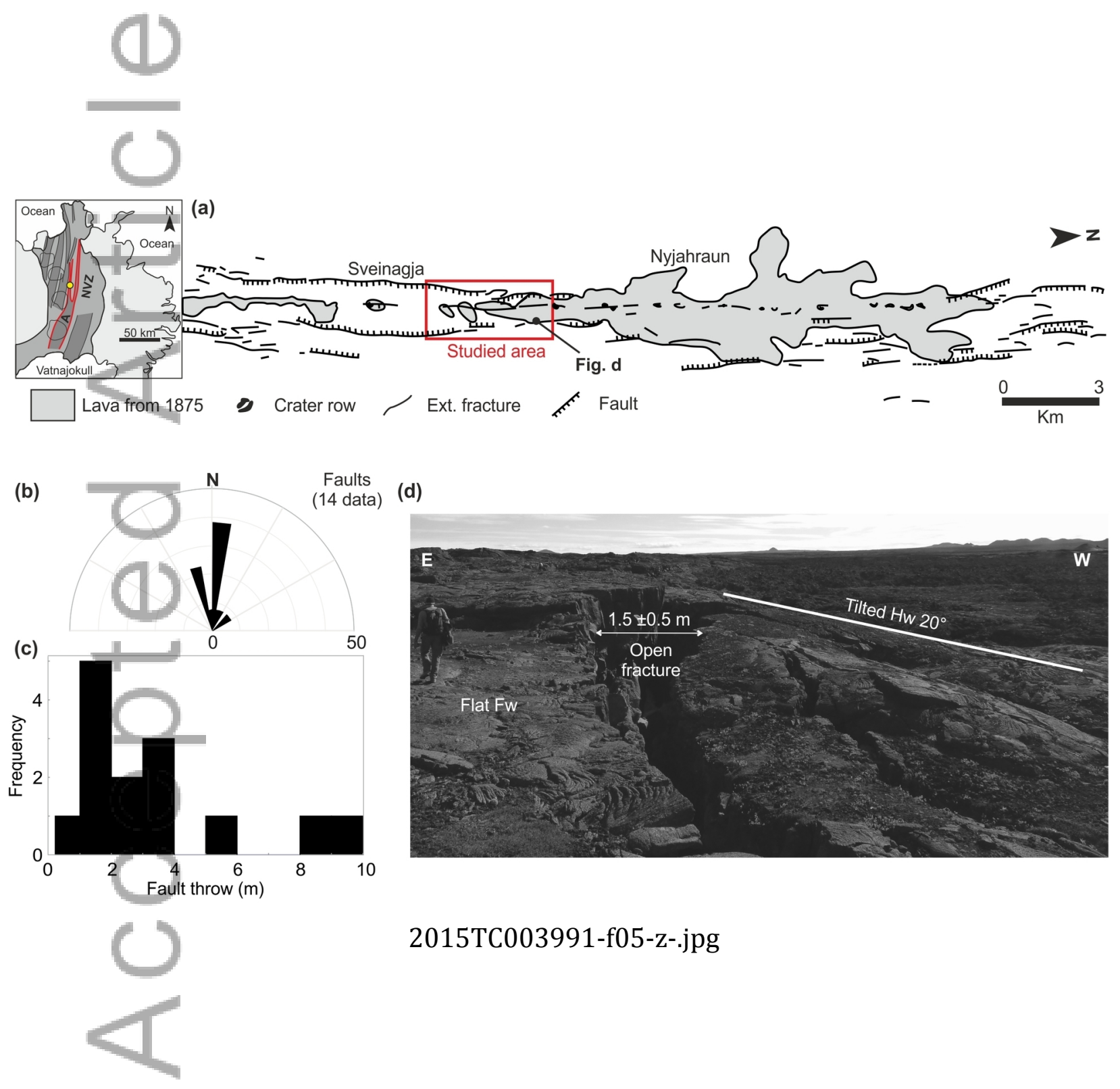

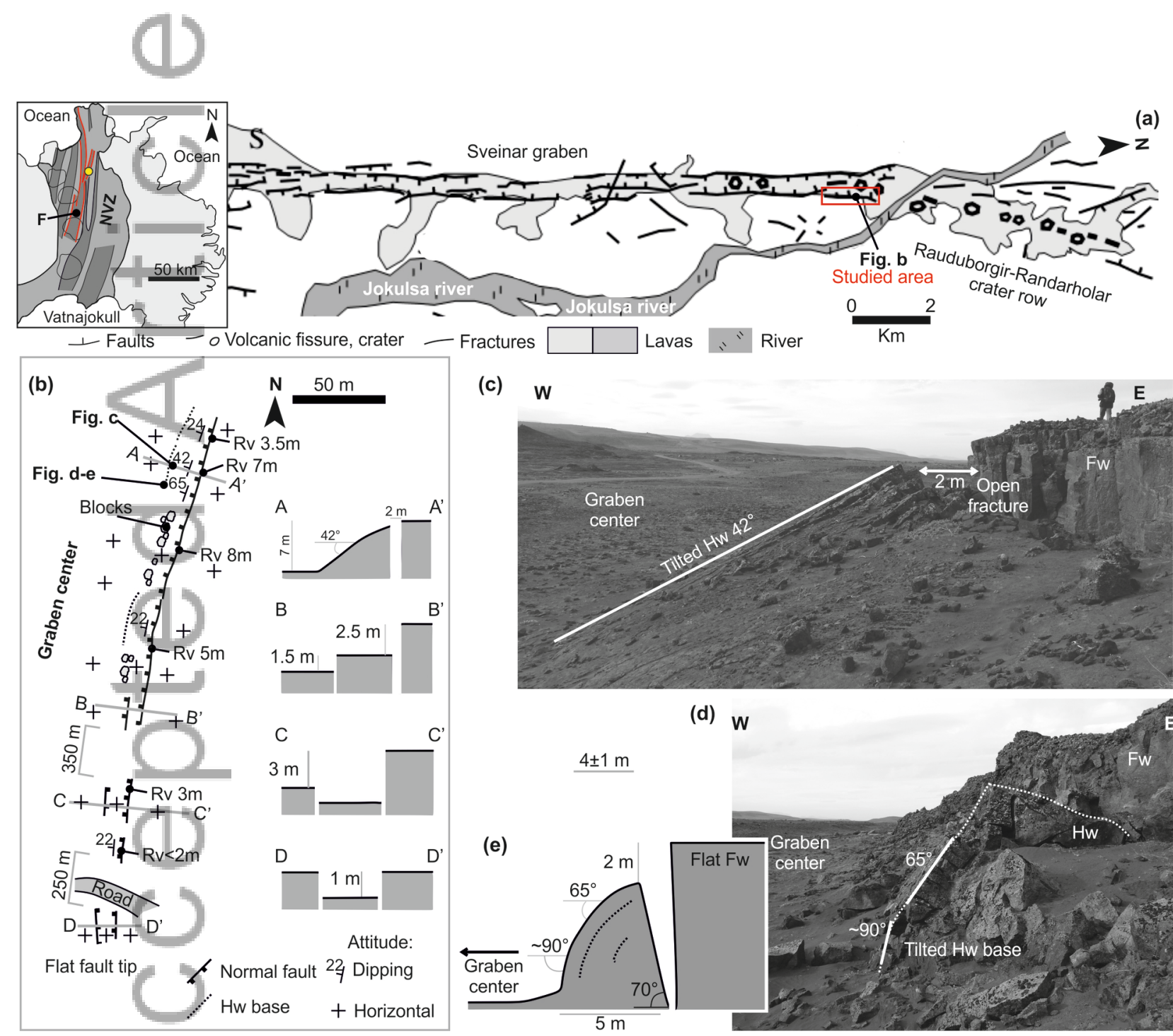

(c) $\mathrm{W}$

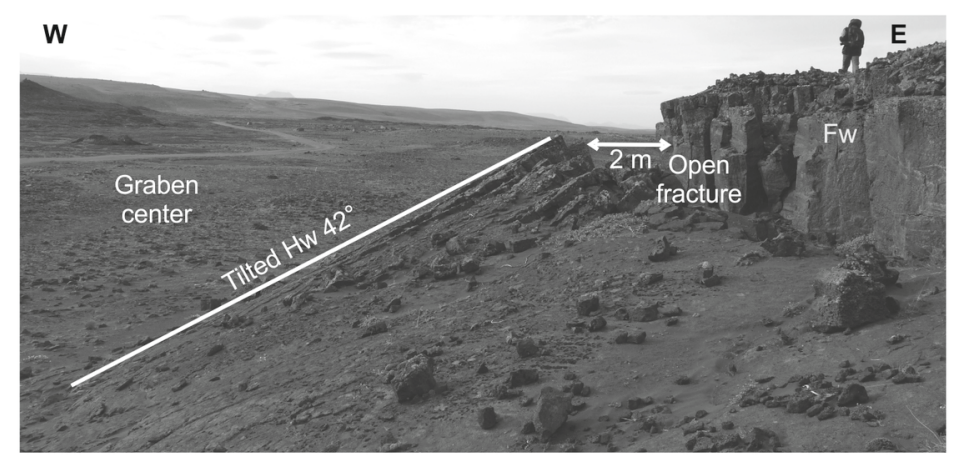

(d) $\mathrm{w}$

'

$4 \pm 1 \mathrm{~m}$

(e)

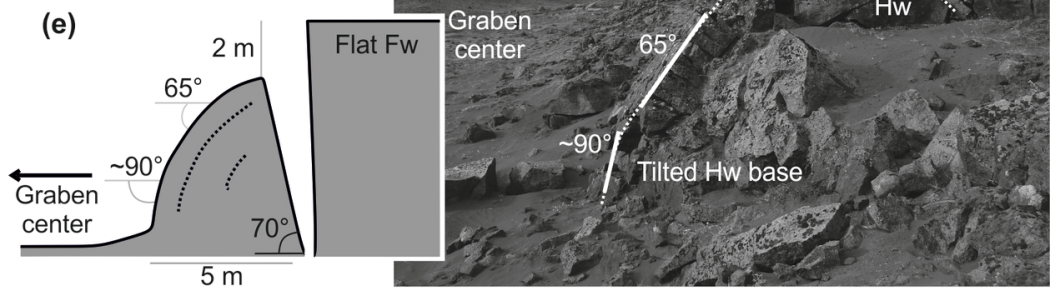

2015TC003991-f06-z-.jpg 

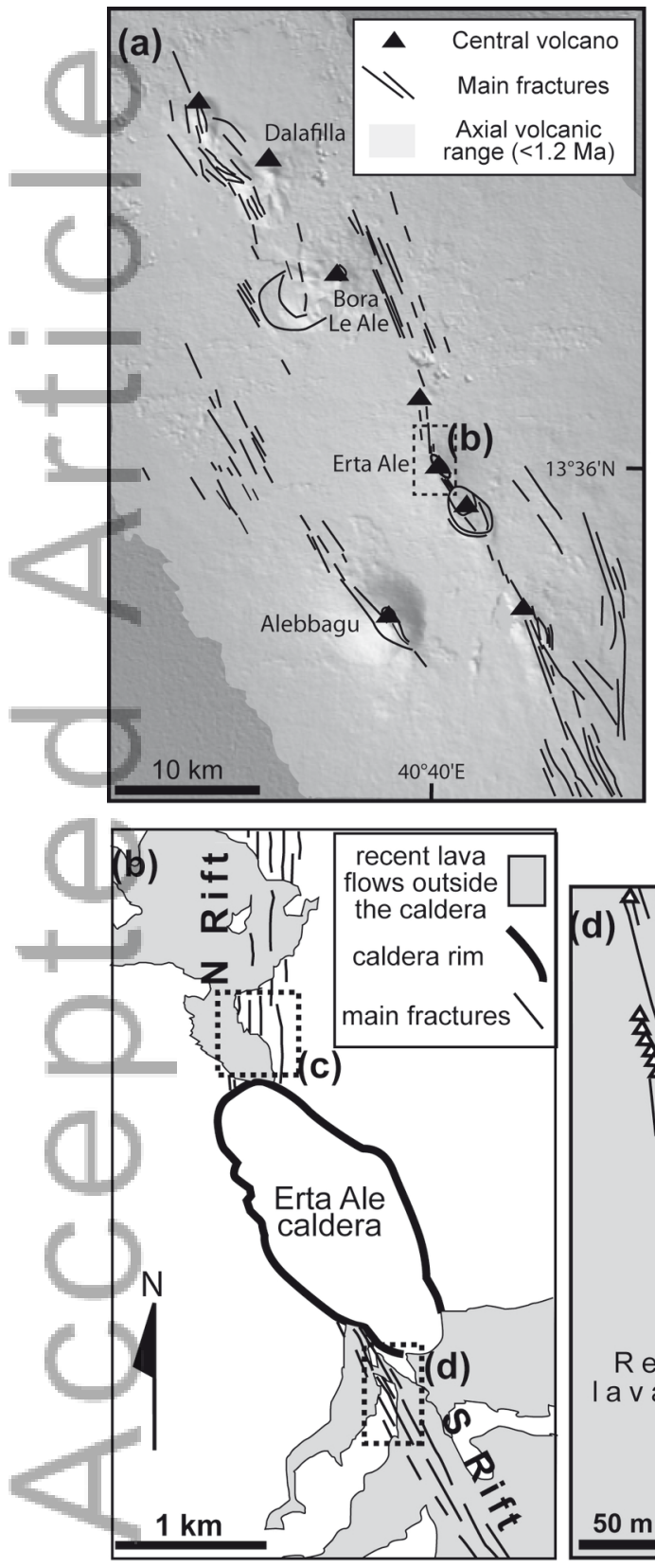

(d)
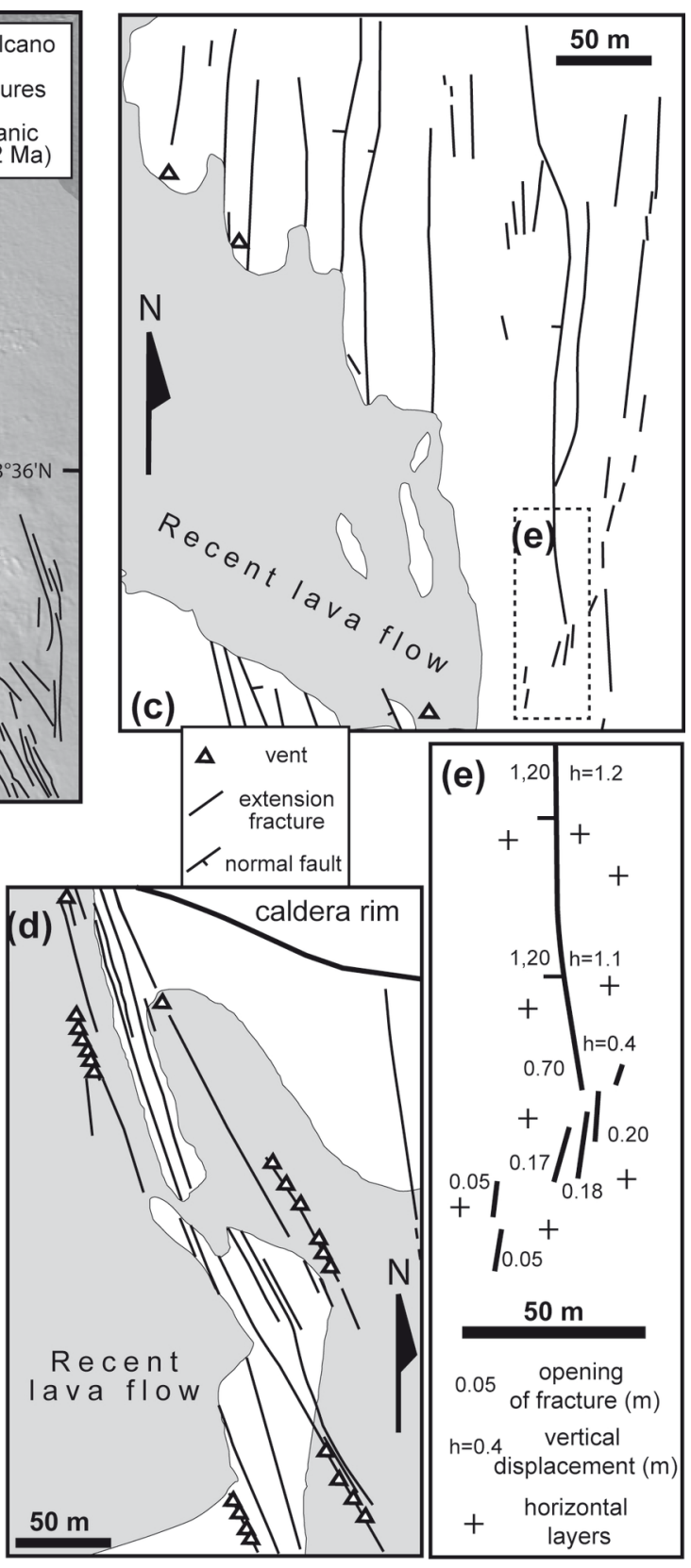

opening

0.4 vertica

horizontal

2015TC003991-f07-z-.jpg 

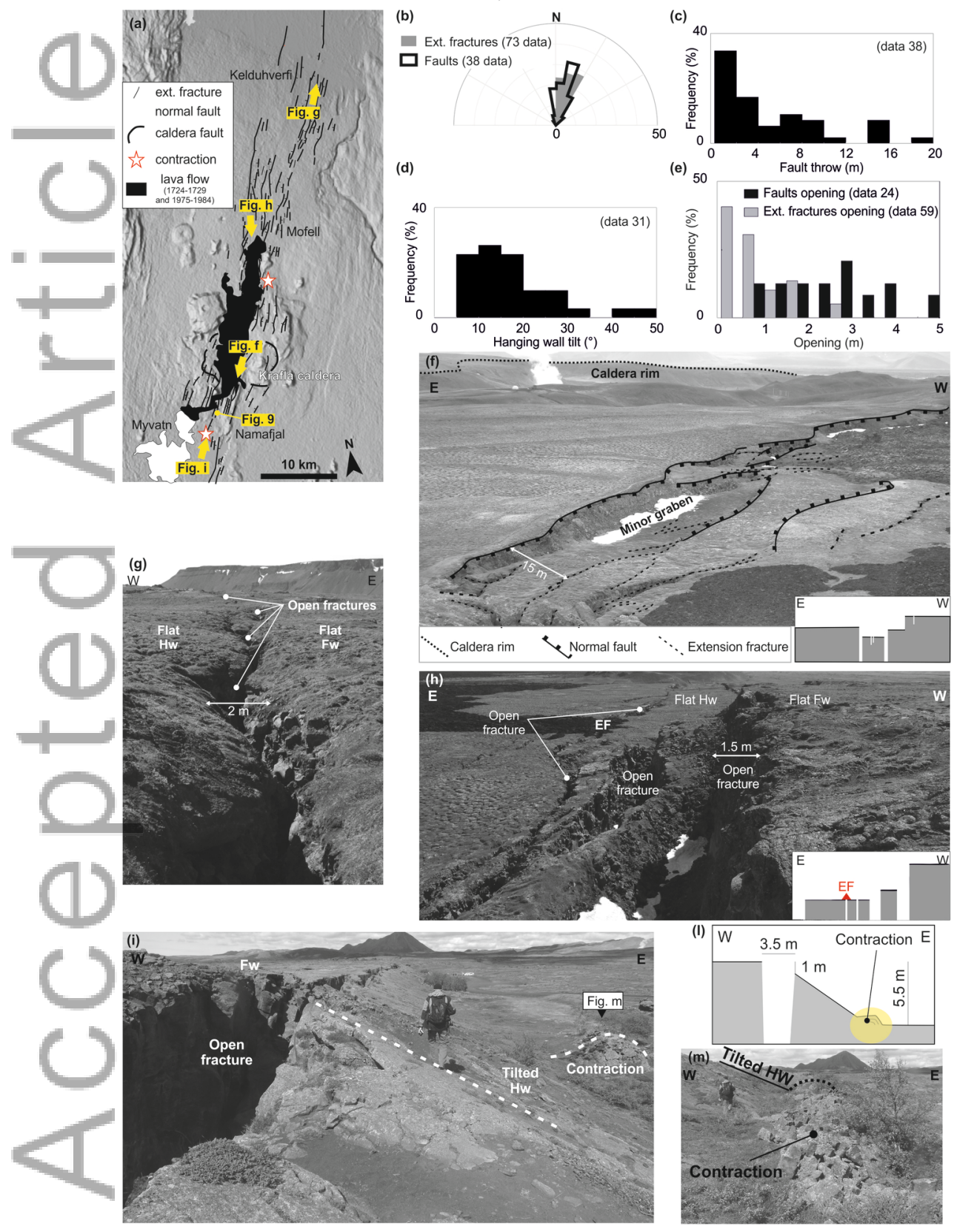

2015TC003991-f08-z-.jpg 


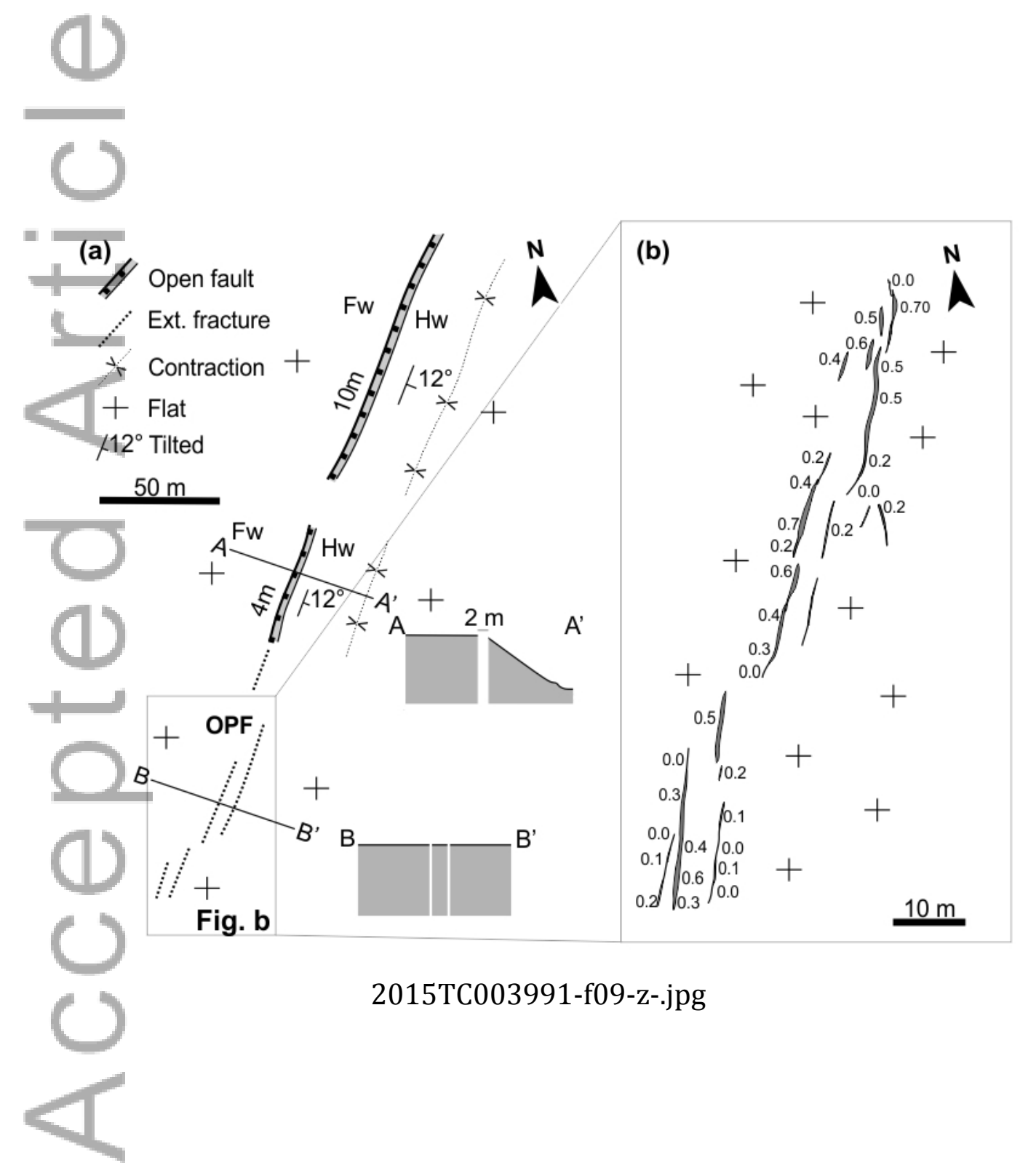

(C)2015 American Geophysical Union. All rights reserved. 

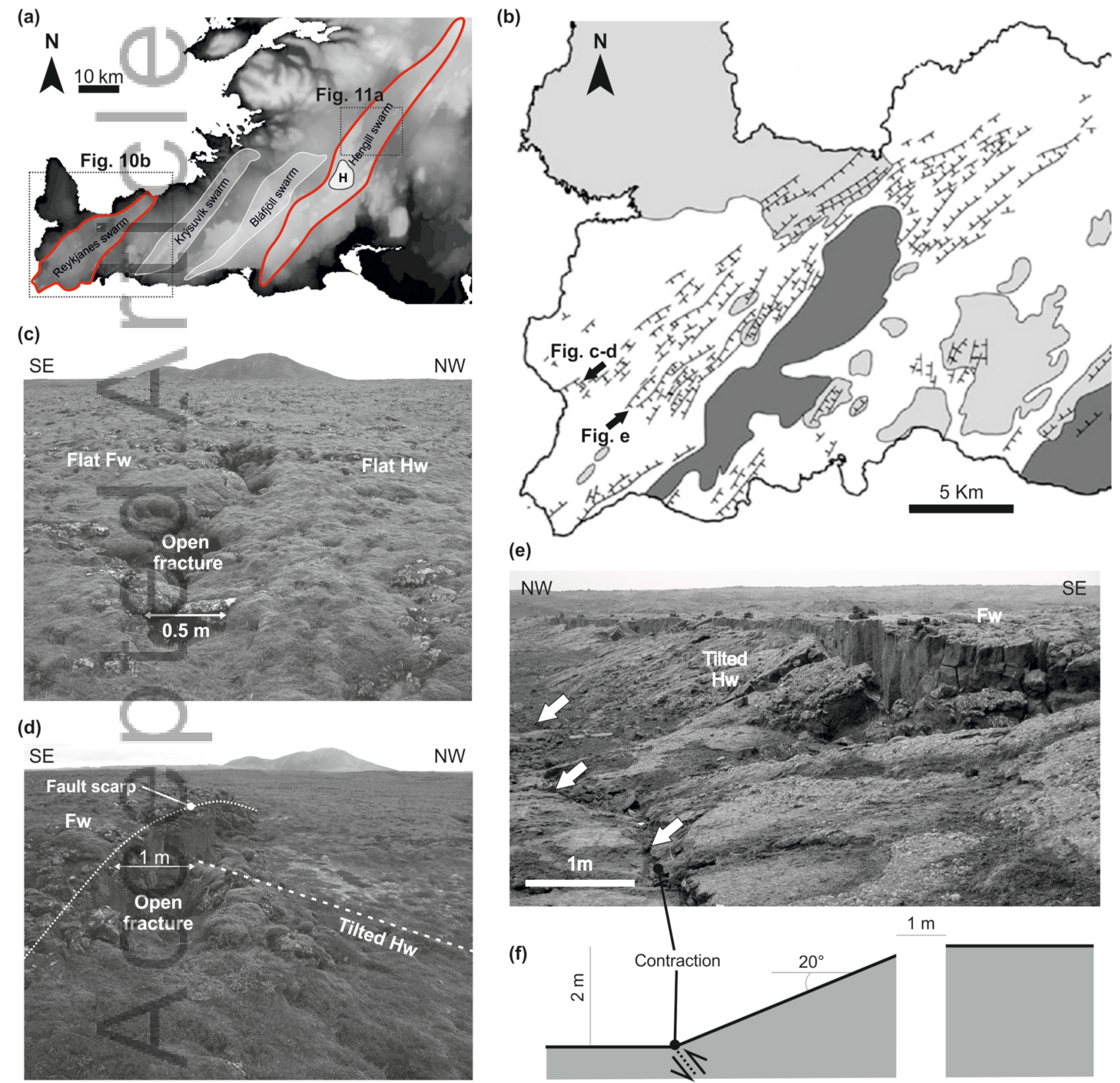

(e)

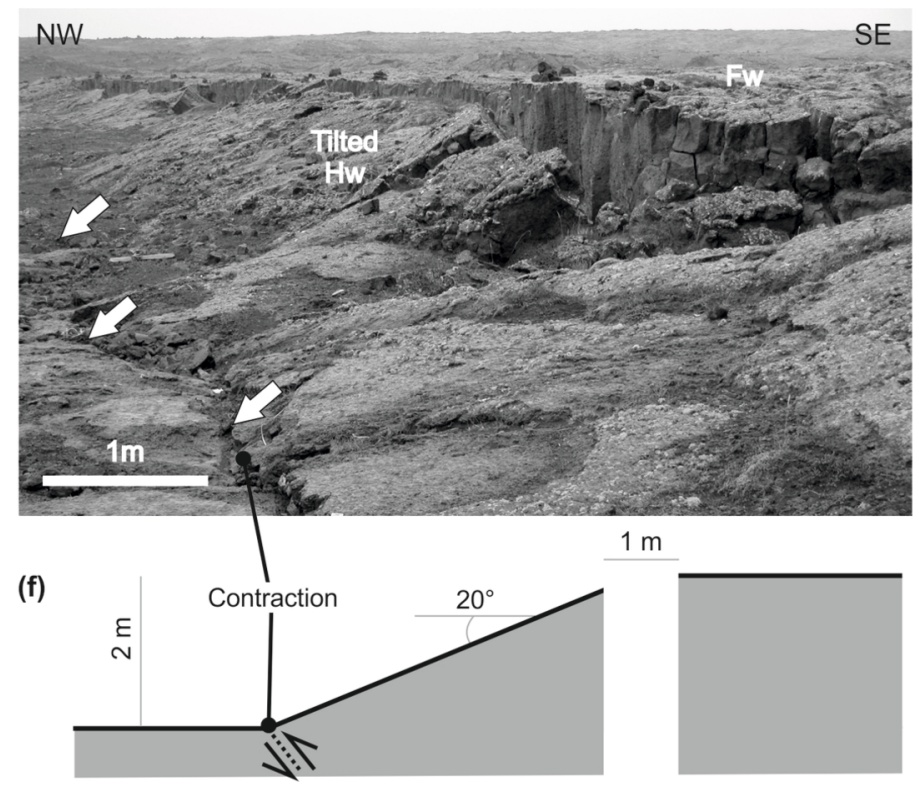

2015TC003991-f10-z-.jpg 


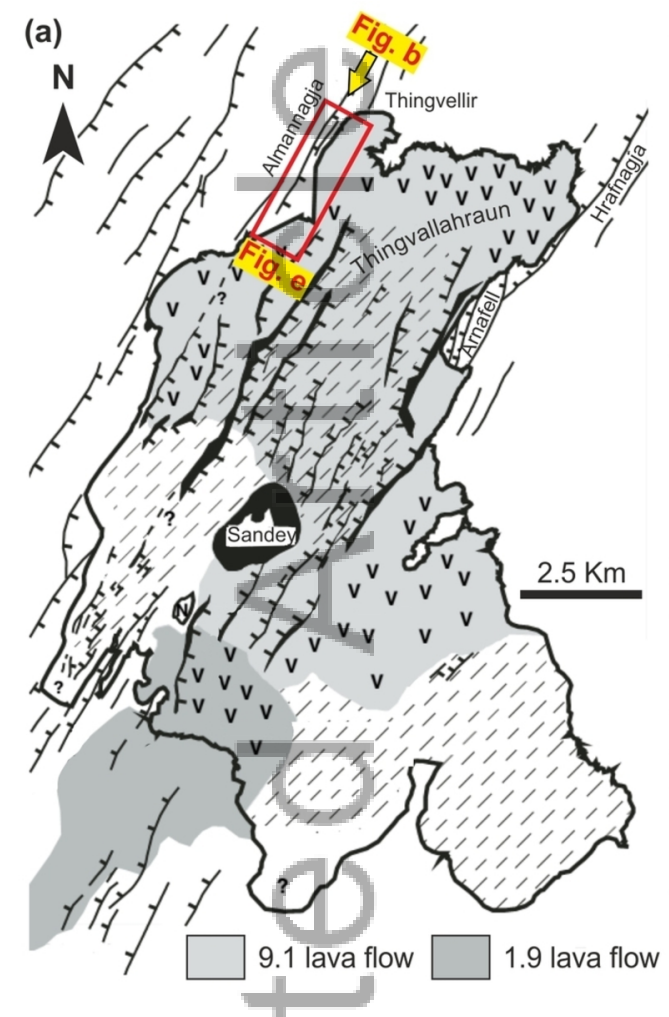

(b)
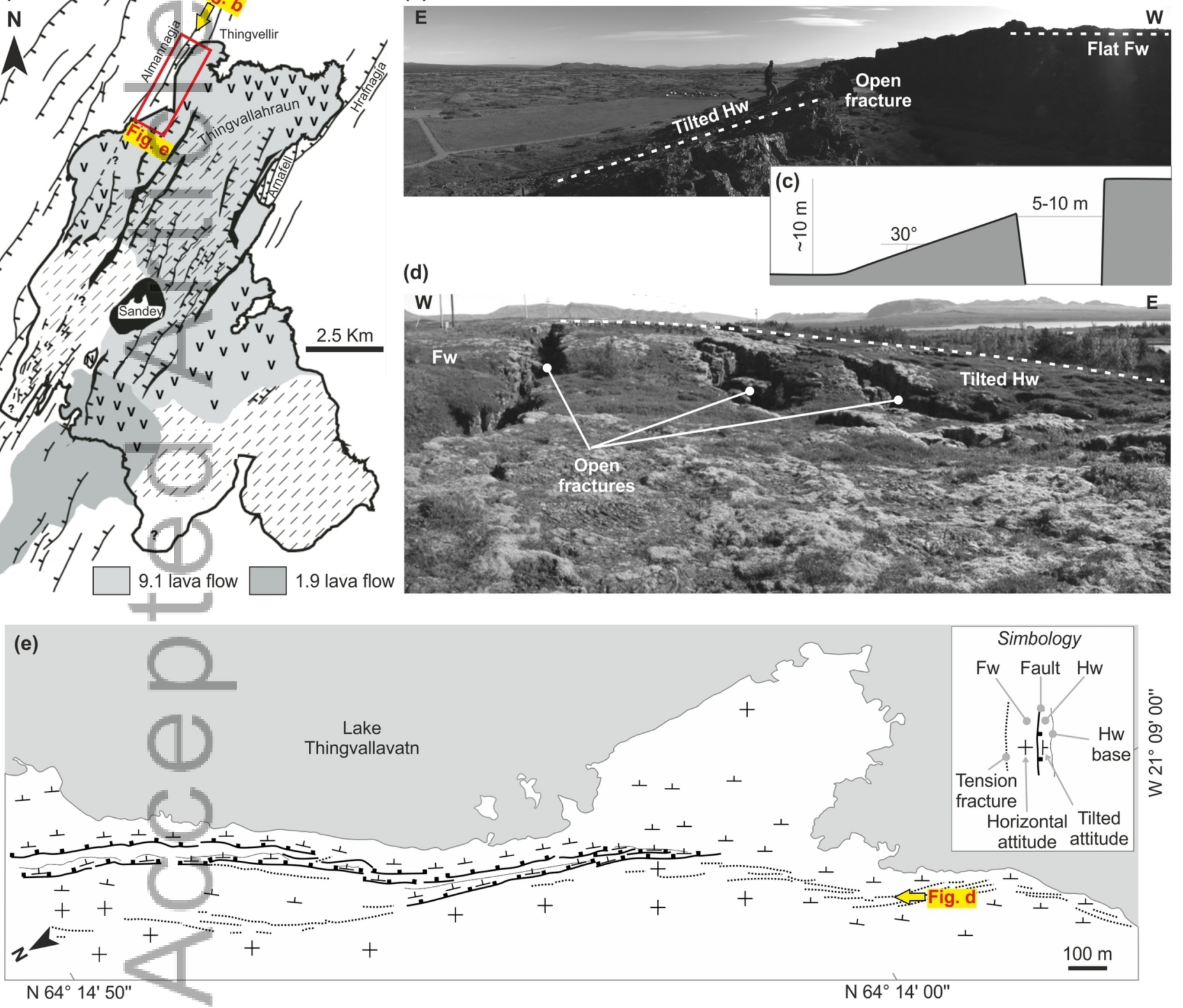

2015TC003991-f11-z-jpg 


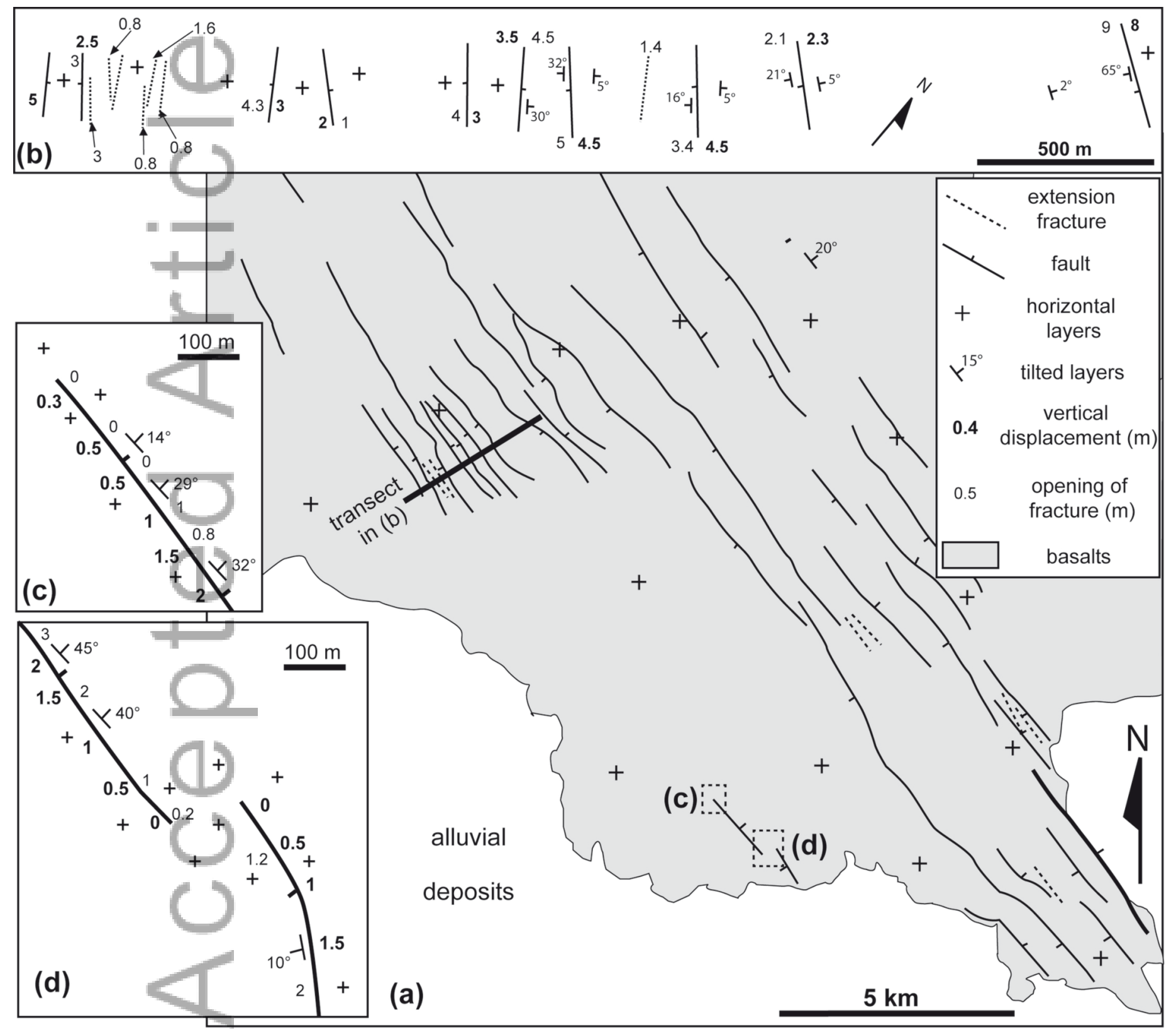

2015TC003991-f12-z-.jpg 
(a)
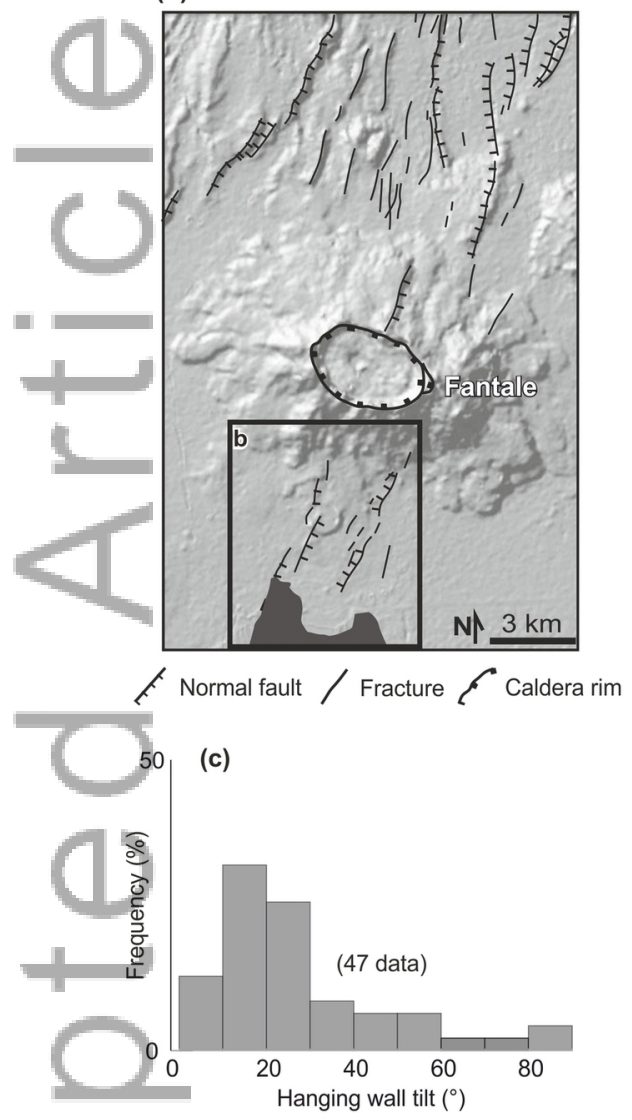

(b)

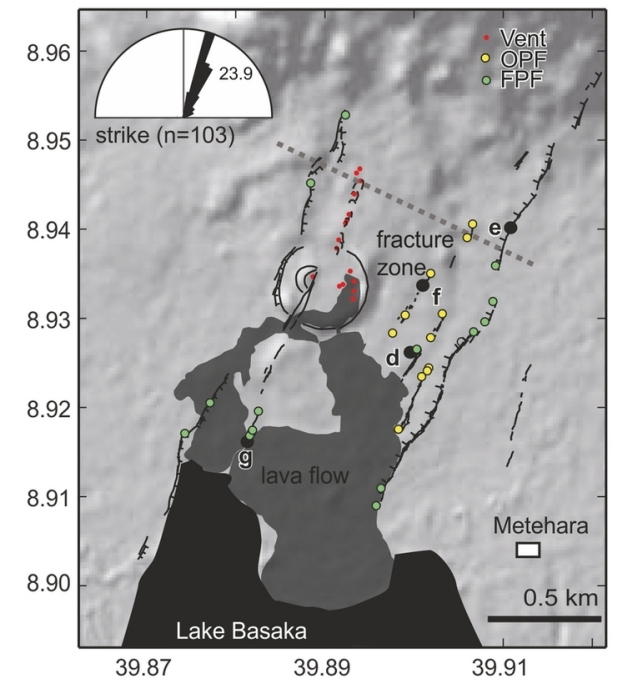

(d)

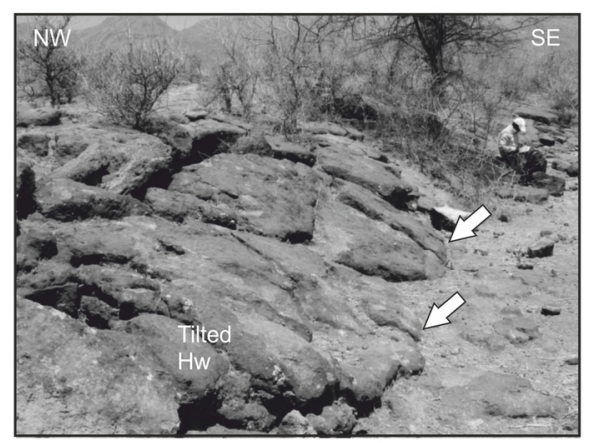

(g)

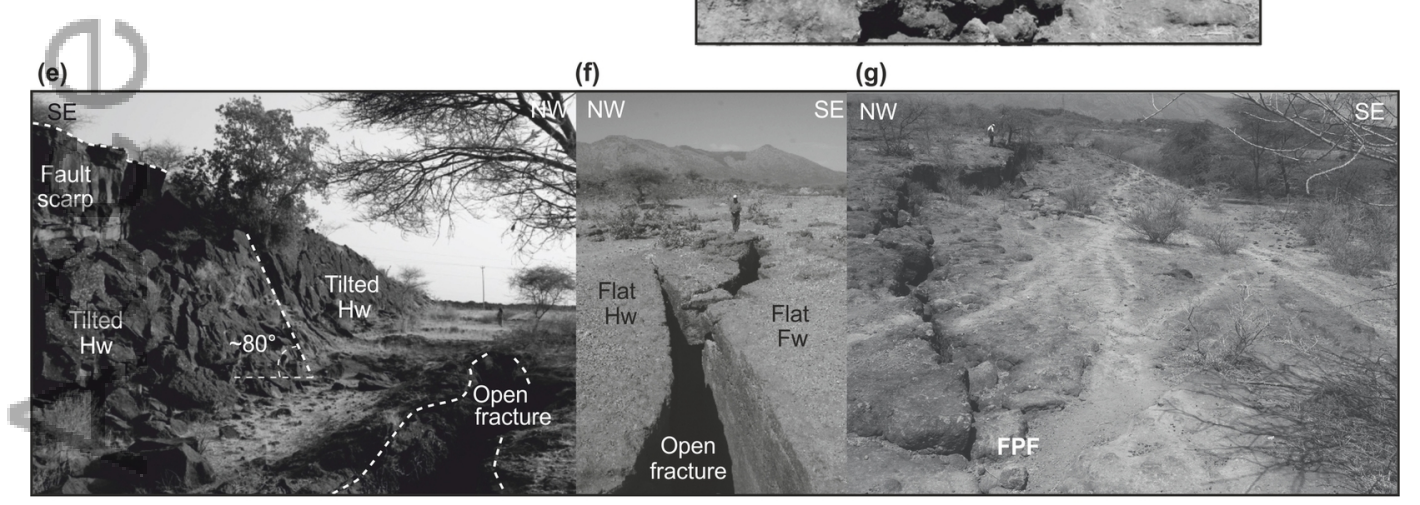

2015TC003991-f13-z-.jpg 

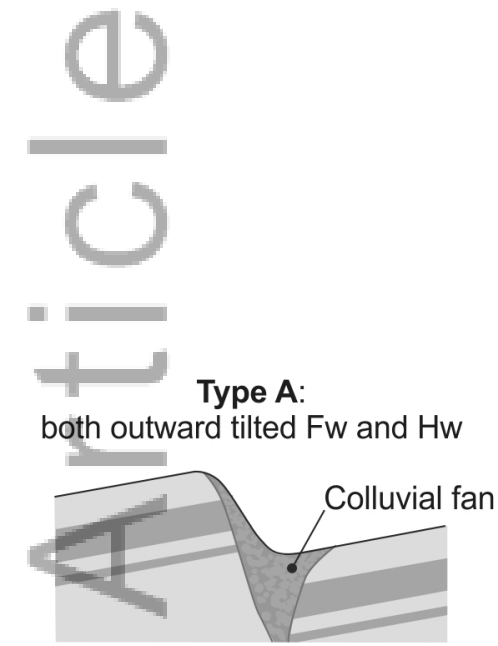

$U(L, E)$

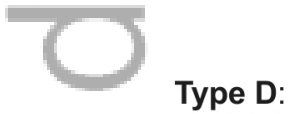

partitioned

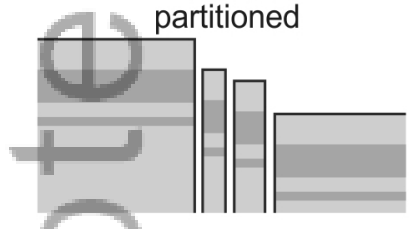

$\mathrm{C}+\mathrm{U}(\mathrm{L}$, Central K, S) $\quad \mathrm{C}(\mathrm{B}$, North $\mathrm{E}$, South $\mathrm{K}, \mathrm{S}, \mathrm{Sv}, \mathrm{T}, \mathrm{V}, \mathrm{F}, \mathrm{MH})$

U: unconsolidated terrains (fall deposits, surge, splatter, debris, etc.)

C: consolidated terrains (lavas, welded tuff, hyaloclastite, etc.)

2015TC003991-f14-z-.jpg
Type B:

both flat Fw and $\mathrm{Hw}$

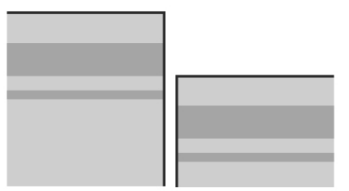

$\mathrm{C}+\mathrm{U}(\mathrm{E}, \mathrm{K}, \mathrm{S}, \mathrm{Sv}, \mathrm{V}, \mathrm{F}, \mathrm{MH})$

Type E:

flat Fw, tilted Hw, local contraction

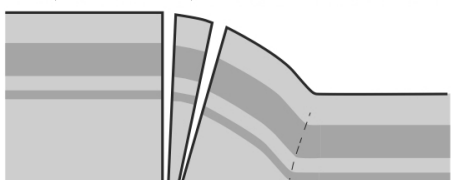

L: Lakagigar

E: Eldjgá

B: Bardarbunga

S: Sveinagja

Sv: Sveinar

K: Krafla

$\mathrm{T}$ : Thingvellir

V: Vogar

$\mathrm{F}$ : Fantale

$\mathrm{MH}$ : Manda Hararo

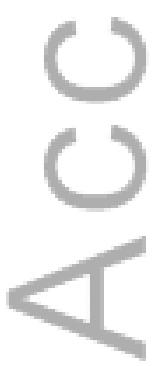




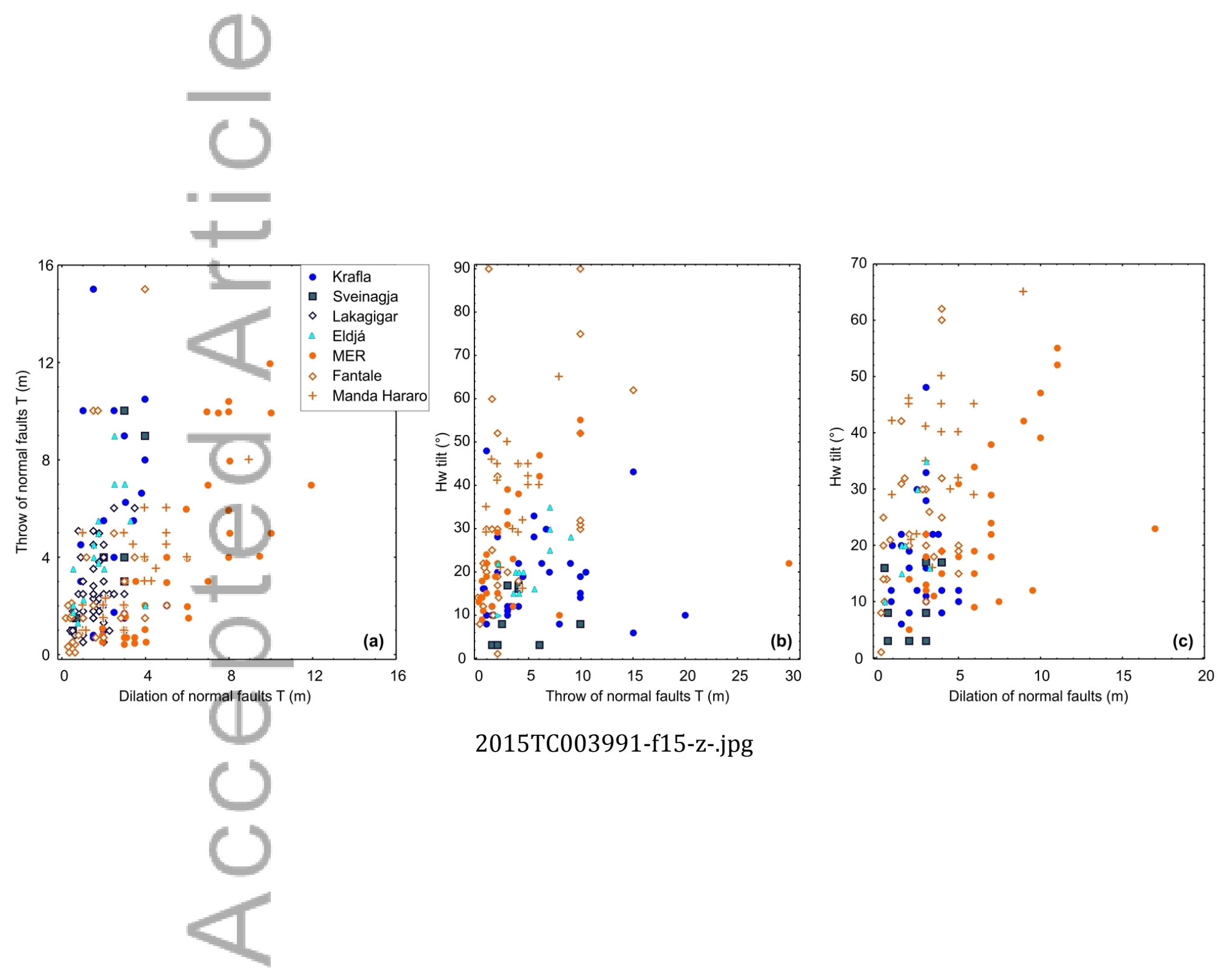




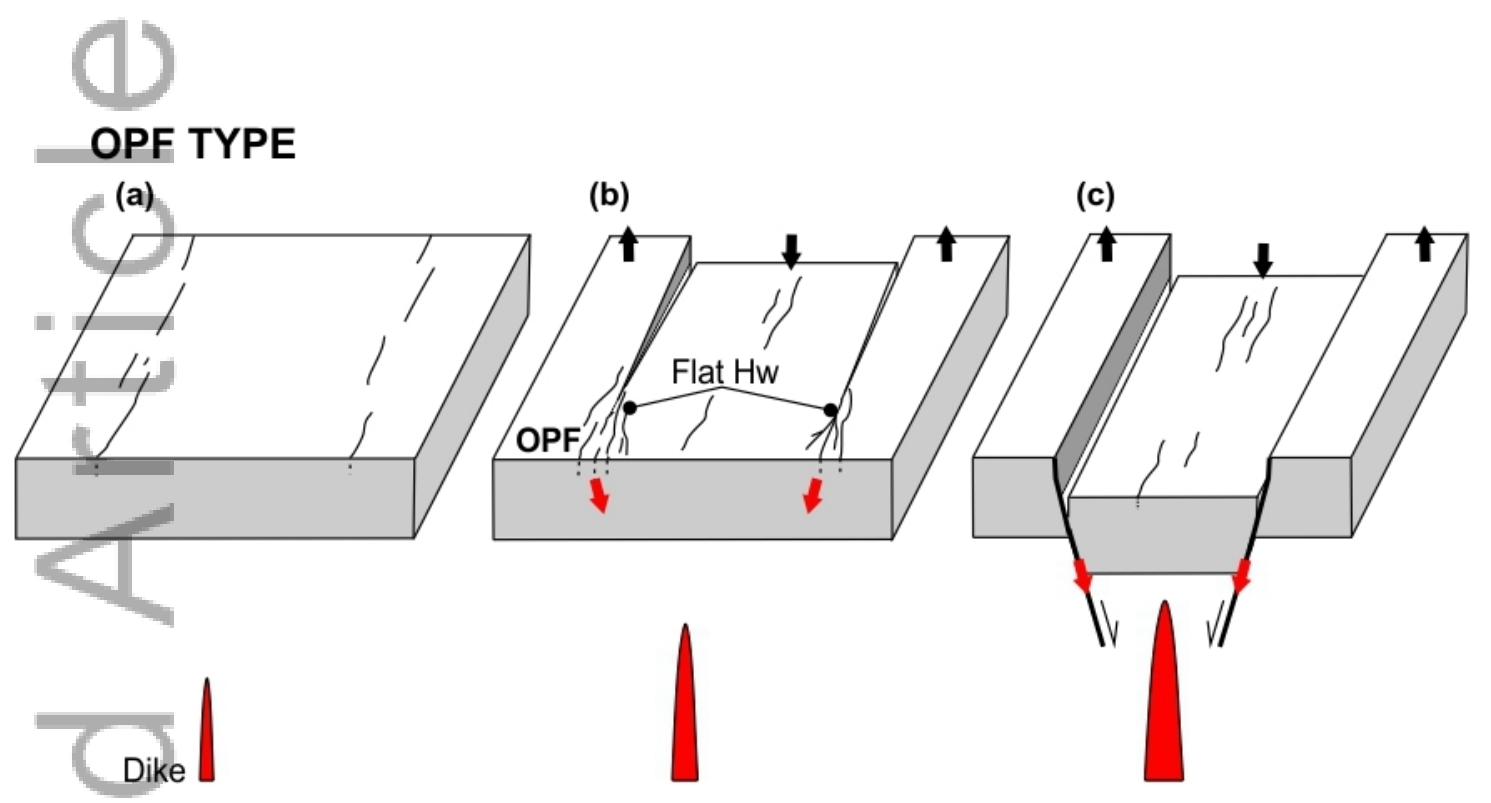

\section{FPF TYPE}

(d)

(e)

(f)

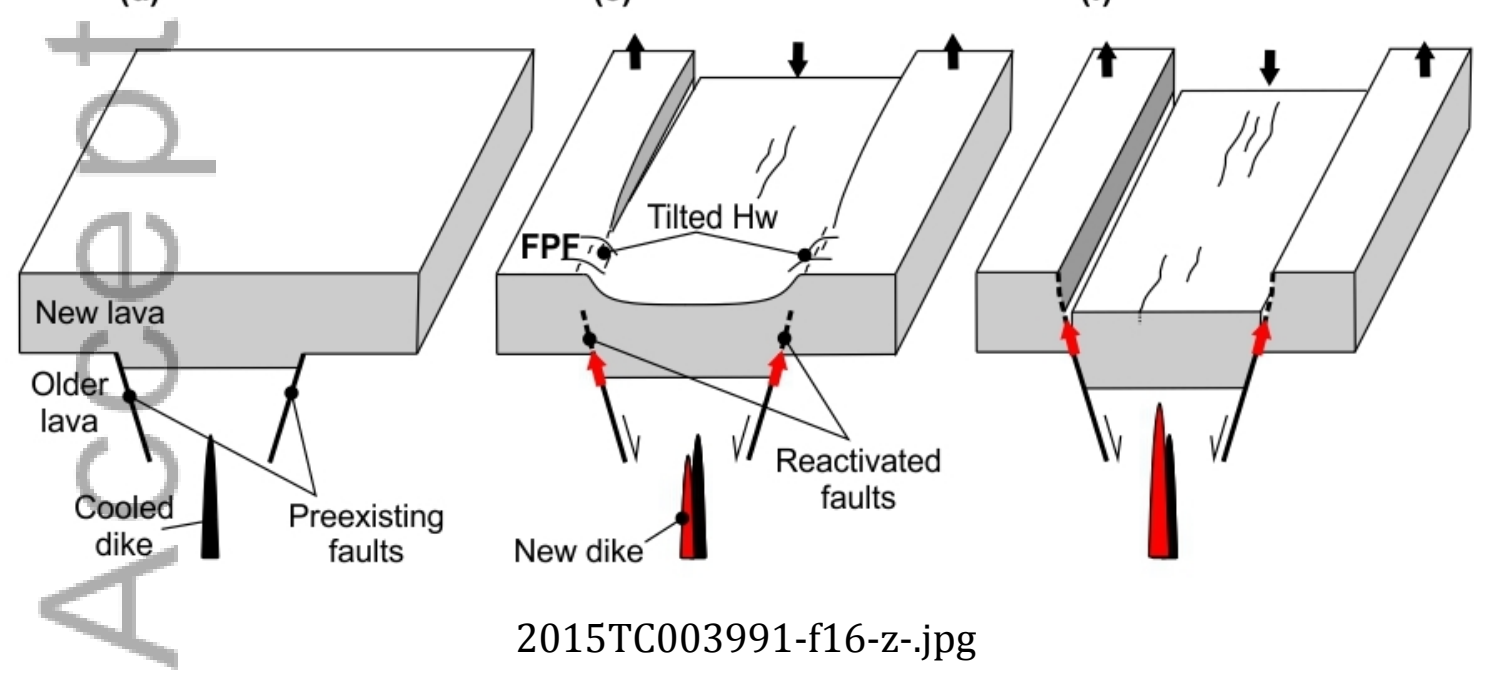




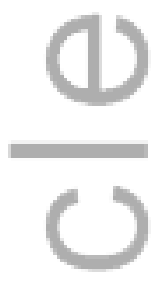

(a)
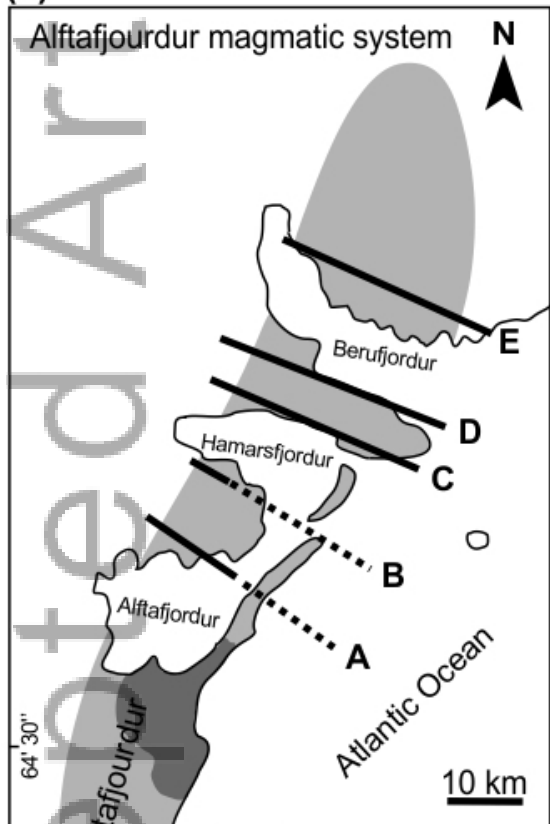

Fissure swarm

Dominant volcano (b)

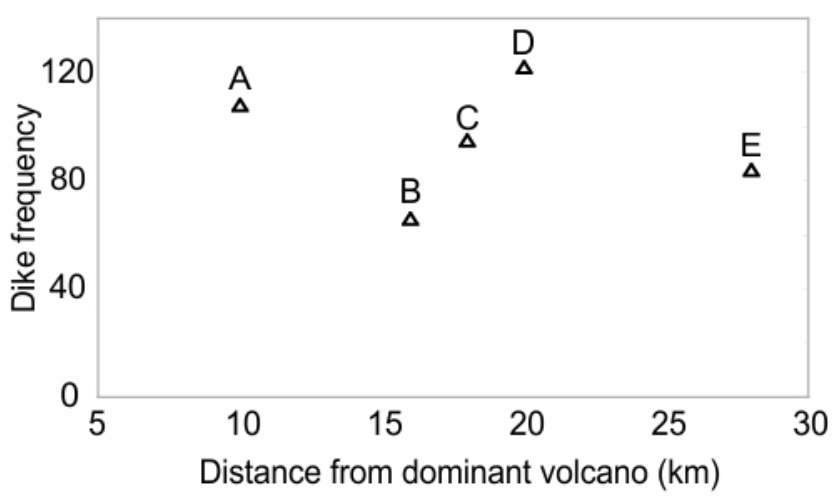

(c)

\section{Section Distance $(\mathbf{k m})$ Dikes Reference}

$\begin{array}{rrrl}\text { A } & 10 & 108 & \text { Paquet et al., 2007 } \\ \text { B } & 16 & 66 & \text { Urbani et al., 2015 } \\ \text { C } & 18 & 95 & \text { Gudmundsson, 1990 } \\ \text { D } & 20 & 122 & \text { Paquet et al., 2007 } \\ \text { E } & 28 & 84 & \text { This study }\end{array}$




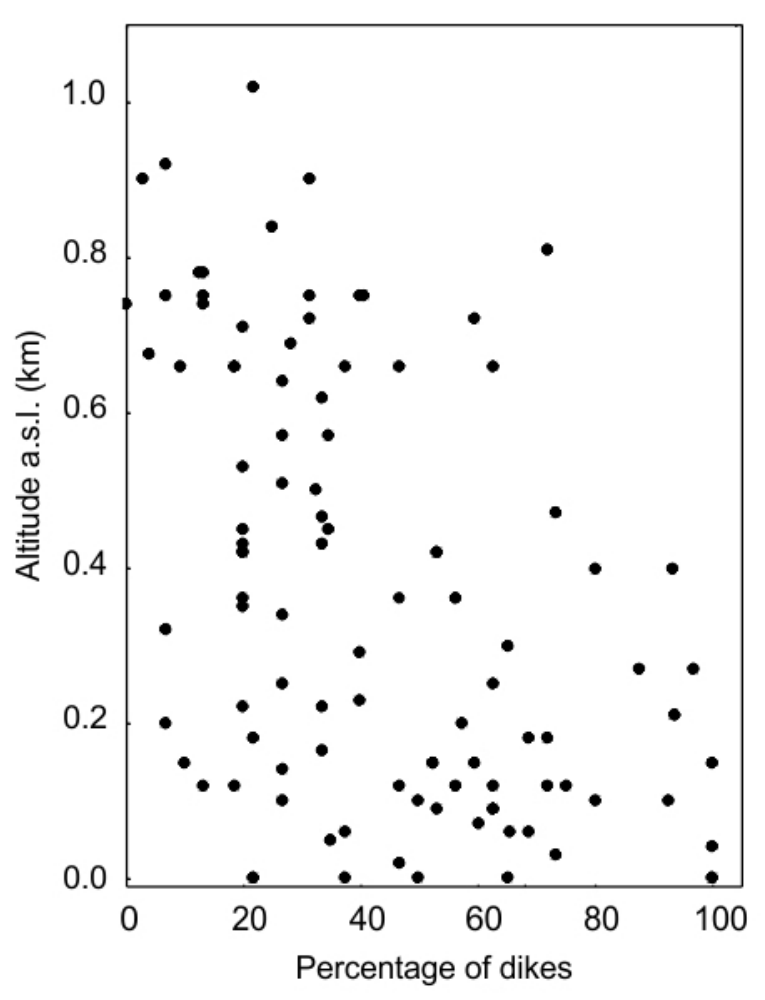

2015TC003991-f18-z-.jpg 


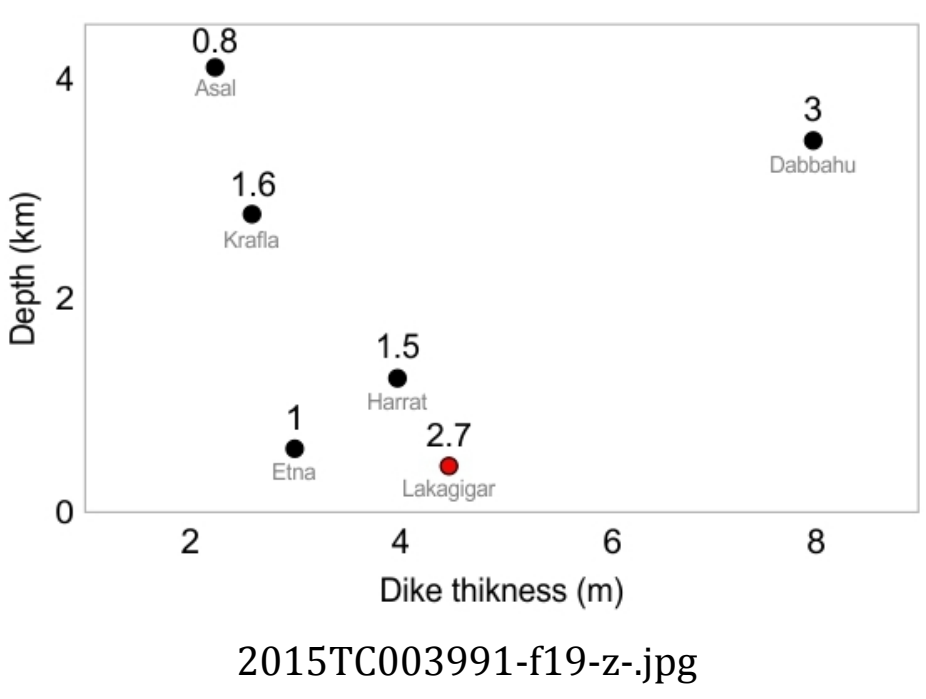

C2015 American Geophysical Union. All rights reserved. 


\begin{tabular}{|c|c|c|c|c|c|c|c|c|c|c|c|c|}
\hline LOCATION & \multicolumn{2}{|c|}{ FAULT TIP } & $\begin{array}{l}\text { GRABEN } \\
\text { WIDTH } \\
(\mathrm{km})\end{array}$ & $\begin{array}{c}\text { MEAN } \\
\text { THROW } \\
( \pm 0.5 \mathrm{~m})\end{array}$ & $\begin{array}{c}\text { MAX } \\
\text { THROW } \\
( \pm 0.5 \mathrm{~m})\end{array}$ & $\begin{array}{c}\text { MEAN } \\
\text { OPENING } \\
( \pm 0.5 \mathrm{~m})\end{array}$ & $\begin{array}{c}\text { MAX } \\
\text { OPENING }\end{array}$ & $\begin{array}{c}\text { MEAN } \\
\text { TILT Hw } \\
\left( \pm 2^{\circ}\right)\end{array}$ & $\begin{array}{c}\text { MAX } \\
\text { TILT Hw }\end{array}$ & EF & C & $\begin{array}{c}\text { EXT. RATE } \\
(\mathrm{mm} / \mathrm{yr})\end{array}$ \\
\hline & $F P F$ & OPF & & & & & & & & & & \\
\hline Lakagigar & 0 & 8 & $0.15-0.40$ & $3.3 \mathrm{~m}$ & $10 \mathrm{~m}$ & $1.4 \mathrm{~m}$ & $3.5 \mathrm{~m}$ & & & $x$ & & 10 \\
\hline Eldgjà NE & 2 & 0 & 0.65 & $5.3 \mathrm{~m}$ & $10 \mathrm{~m}$ & $1.6 \mathrm{~m}$ & $3.3 \mathrm{~m}$ & $16^{\circ}$ & $30^{\circ}$ & & & 9 \\
\hline Eldgjà C & & & 0.16 & $4.6 \mathrm{~m}$ & $10 \mathrm{~m}$ & $1.5 \mathrm{~m}$ & $4.0 \mathrm{~m}$ & $24^{\circ}$ & $24^{\circ}$ & $x$ & & 9 \\
\hline Eldgjà SW & & & 0.23 & $4.8 \mathrm{~m}$ & $10 \mathrm{~m}$ & $1.7 \mathrm{~m}$ & $3.0 \mathrm{~m}$ & $32^{\circ}$ & $35^{\circ}$ & $x$ & & 9 \\
\hline Sveinagja & 0 & 5 & $1.00-1.70$ & $3.7 \mathrm{~m}$ & $10 \mathrm{~m}$ & $2.1 \mathrm{~m}$ & $13.0 \mathrm{~m}$ & $13^{\circ}$ & $17^{\circ}$ & $x$ & & 19 \\
\hline Sveinar & 0 & 1 & $0.50-0.80$ & $3.8 \mathrm{~m}$ & $8 \mathrm{~m}$ & $2.0 \mathrm{~m}$ & $2.5 \mathrm{~m}$ & $32^{\circ}$ & $65^{\circ}$ & $x$ & $x$ & 19 \\
\hline Erta Ale & 0 & 1 & 0.2 & $1.0 \mathrm{~m}$ & $2.5 \mathrm{~m}$ & $1.5 \mathrm{~m}$ & $2.7 \mathrm{~m}$ & $0^{\circ}$ & $0^{\circ}$ & $x$ & & 12 \\
\hline Krafla & 1 & 18 & $3.00-9.00$ & $5.5 \mathrm{~m}$ & $42 \mathrm{~m}$ & $2.7 \mathrm{~m}$ & $28.0 \mathrm{~m}$ & $17^{\circ}$ & $48^{\circ}$ & $x$ & $x$ & 23 \\
\hline Thingvellir & 22 & 4 & 5.00 & $8.0 \mathrm{~m}$ & $11 \mathrm{~m}$ & $14.0 \mathrm{~m}$ & $68.0 \mathrm{~m}$ & $15^{\circ}$ & $40^{\circ}$ & & & 5 \\
\hline Vogar & 35 & 7 & $3.00-4.50$ & $6.0 \mathrm{~m}$ & $9 \mathrm{~m}$ & $3.0 \mathrm{~m}$ & $8.0 \mathrm{~m}$ & $30^{\circ}$ & & & $x$ & 6 \\
\hline Fantale & 14 & 12 & $2.50-2.70$ & $3.5 \mathrm{~m}$ & $20 \mathrm{~m}$ & $2.3 \mathrm{~m}$ & $5.0 \mathrm{~m}$ & $30^{\circ}$ & $88^{\circ}$ & $x$ & $x$ & 7 \\
\hline Manda Hararo & 0 & 3 & 10 & $2.9 \mathrm{~m}$ & $10 \mathrm{~m}$ & $3.8 \mathrm{~m}$ & $9 \mathrm{~m}$ & $37^{\circ}$ & $65^{\circ}$ & $x$ & & $1-15$ \\
\hline
\end{tabular}

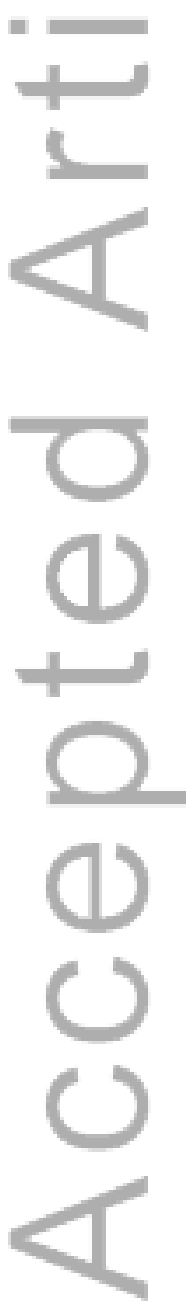

